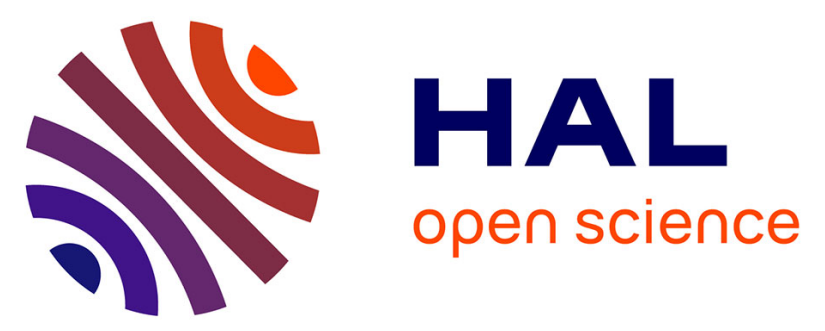

\title{
The interplay between climate and tectonics during the upward and outward growth of the Qilian Shan orogenic wedge, northern Tibetan Plateau
}

Feng Cheng, Carmala Garzione, Gautam Mitra, Marc Jolivet, Zhaojie Guo, Huayu Lu, Xiangzhong Li, Bo Zhang, Changhao Zhang, Hanzhi Zhang, et al.

\section{To cite this version:}

Feng Cheng, Carmala Garzione, Gautam Mitra, Marc Jolivet, Zhaojie Guo, et al.. The interplay between climate and tectonics during the upward and outward growth of the Qilian Shan orogenic wedge, northern Tibetan Plateau. Earth-Science Reviews, 2019, 198, pp.102945. 10.1016/j.earscirev.2019.102945 . insu-02277923

\section{HAL Id: insu-02277923 \\ https://hal-insu.archives-ouvertes.fr/insu-02277923}

Submitted on 4 Sep 2019

HAL is a multi-disciplinary open access archive for the deposit and dissemination of scientific research documents, whether they are published or not. The documents may come from teaching and research institutions in France or abroad, or from public or private research centers.
L'archive ouverte pluridisciplinaire HAL, est destinée au dépôt et à la diffusion de documents scientifiques de niveau recherche, publiés ou non, émanant des établissements d'enseignement et de recherche français ou étrangers, des laboratoires publics ou privés. 


\section{Journal Pre-proof}

The interplay between climate and tectonics during the upward and outward growth of the Qilian Shan orogenic wedge, northern Tibetan Plateau

Feng Cheng, Carmala N. Garzione, Gautam Mitra, Marc Jolivet, Zhaojie Guo, Huayu Lu, Xiangzhong Li, Bo Zhang, Changhao

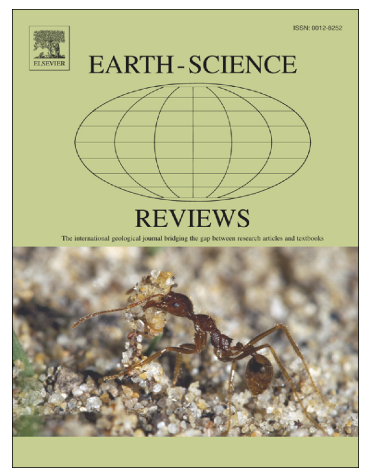
Zhang, Hanzhi Zhang, Lin Wang

PII: $\quad$ S0012-8252(19)30241-7

DOI: $\quad$ https://doi.org/10.1016/j.earscirev.2019.102945

Reference: $\quad$ EARTH 102945

To appear in: $\quad$ Earth-Science Reviews

Received date: $\quad 15$ April 2019

Revised date: $\quad 30$ August 2019

Accepted date: $\quad 31$ August 2019

Please cite this article as: F. Cheng, C.N. Garzione, G. Mitra, et al., The interplay between climate and tectonics during the upward and outward growth of the Qilian Shan orogenic wedge, northern Tibetan Plateau, Earth-Science Reviews(2018), https:/doi.org/10.1016/ j.earscirev.2019.102945

This is a PDF file of an article that has undergone enhancements after acceptance, such as the addition of a cover page and metadata, and formatting for readability, but it is not yet the definitive version of record. This version will undergo additional copyediting, typesetting and review before it is published in its final form, but we are providing this version to give early visibility of the article. Please note that, during the production process, errors may be discovered which could affect the content, and all legal disclaimers that apply to the journal pertain.

(C) 2018 Published by Elsevier. 
The interplay between climate and tectonics during the upward and outward growth of the Qilian Shan orogenic wedge, northern Tibetan Plateau

Feng Cheng ${ }^{1,2, \dagger}$, Carmala N. Garzione ${ }^{1,3}$, Gautam Mitra ${ }^{1}$, Marc Jolivet ${ }^{4}$, Zhaojie Guo ${ }^{5}$, Huayu $\mathrm{Lu}^{6}$, Xiangzhong $\mathrm{Li}^{2,7}$, Bo Zhang ${ }^{5}$, Changhao Zhang ${ }^{8}$, Hanzhi Zhang ${ }^{6}$, Lin Wang ${ }^{9, \dagger}$

${ }^{1}$ Department of Earth and Environmental Sciences, University of Rochester, Rochester, $N Y$ 14627, USA

${ }^{2}$ State Key Laboratory of Loess and Quaternary Geology, Institute of Earth Environment, Chinese Academy of Science, Xi'an, 710061, China

${ }^{3}$ Department of Environmental Sciences, Rochester Institute of Technology, Rochester, NY, 14623, USA

${ }^{4}$ Laboratoire Géosciences Rennes, CNRS-UMR61 18, Université Rennes 1, Observatoire des Sciences de l'Univers, Rennes, 35042, France

${ }^{5}$ Key Laboratory of Orogenic Belts and Crustal Evolution, Ministry of Education, School of Earth and Space Sciences, Peking University, Beijing, 100871, China

${ }^{6}$ School of Geography and Ocean Science, Nanjing University, Nanjing, 210023, China

${ }^{7}$ Research Center for Earth System Science, Yunnan University, Kunming, 650504, China

${ }^{8}$ Qinghai Oilfield Company, PetroChina, Dunhuang, Gansu, 736202, China

${ }^{9}$ College of Engineering, Peking University, Beijing 100871, China

${ }^{\dagger}$ Corresponding author.E-mail address: cfcf.chengfeng@gmail.com; linzi@pku.edu.cn 


\section{Abstract}

Mountains grow upward and outward when the accretion of material outpaces its removal. Mountain building is synergistically influenced by geodynamics, internal structures (crustal and lithospheric), and climate. The northward growth of the Qilian Shan, which occupies a transition zone between the $\sim 4500 \mathrm{~m}$ high central Tibetan plateau and the adjacent $<2000$ m high North China craton to the northeast, figures into debates of active orogenic wedge evolution. In this study, we integrate new detrital zircon $\mathrm{U}-\mathrm{Pb}$ geochronological data with interpretation of seismic profiles and drill core data from the NE Qaidam and Suganhu basins to investigate both the relief building in the Qilian Shan wedge and the source to sink relationship between the Qilian Shan and adjacent basins through time. While intensive crustal shortening within the Qilian Shan during the Paleogene, landward retrogradation of alluvial-fluvial facies in both northeastern and southern Qaidam basin as well as an increasing proportion of Mesozoic to Late Paleozoic and Precambrian detrital zircon ages reveal a basin-scale expansion of drainage area. The connection between the NE Qaidam and the Suganhu basins, as well as the southern Qilian Shan was finally cut off during the Miocene. Combining published regional climate records with provenance data from Cenozoic strata in the Qaidam basin, we infer that increased precipitation under relatively warm and wet climate conditions drove basin-scale transgression during the Paleogene. Since then, the Qaidam basin has been gradually isolated in response to the intensified deformation within the surrounding mountain belts and the regional aridification. We propose the Cenozoic growth of the Qilian Shan could obey critical-taper wedge theory. The climate driven erosion defeated the tectonic thickening in the southern Qilian Shan prior to the Miocene and caused the Qilian Shan wedge to stall. Deformation remained localized in the southern Qilian Shan as wedge taper continued to build. Since the Miocene, decreased erosion of the wedge under arid to semi-arid conditions has allowed deformation to maintain a high enough wedge taper 
to allow for northward propagation of the deformation front into the central and northern

Qilian Shan. This study highlights the significant influence of previously unconsidered regional climate in upward and outward growth in the northern Tibetan plateau. The Cenozoic evolution of northern Tibetan plateau cannot be evaluated without an understanding of how climate may have played into the kinematic history.

Keyword: Climate versus tectonics; Critical taper theory; Northern Tibetan plateau; Provenance analysis; Seismic profile interpretation

\section{Highlight}

- Thrusting in the southern Qilian Shan initiated during the Paleogene

- Qaidam basin expanded before the Miocene and was gradually isolated since then

- Climate interplay with tectonics contributed to the northward growth of the Qilian Shan

- The evolution of the Qilian Shan wedge can be reconciled with critical taper theory 


\section{Introduction}

Topographic analyses that are based on low-temperature thermochronology, provenance analysis and numerical modeling studies have shown that global and/or local climate fluctuation can affect the tectonic evolution of mountain ranges (Herman et al., 2013; Masek et al., 1994; Montgomery et al., 2001; Whipple, 2009). Temporally and spatially changing erosion rates and patterns associated with climate change can modify the exhumation pattern (and thus the localization of the deformation) and thereby modulate the morphology and structure of mountain ranges (Champagnac et al., 2012; Grujic et al., 2006; Lease et al., 2016).

The upward and outward growth of mountains can be generally viewed as a process of mass addition that outpaces its removal; thus climate, interior structure (both crustal and lithospheric) and geodynamics modify the orogenic wedge and exert significant controls on the process of mountain building (Carrapa, 2009; DeCelles and Mitra, 1995; Lease et al., 2016; Roe et al., 2008; Searle et al., 2017; Whipple, 2009; Willett, 1999). The growth of most contractional mountain belts can be, at first order, reasonably described using the critical taper orogenic wedge model (Dahlen, 1990; Dahlen and Suppe, 1988; Davis et al., 1983; DeCelles and Mitra, 1995; Elliott, 1976; Lallemand et al., 1994; Lease et al., 2016; Roe et al., 2008; Suppe and Medwedeff, 1990). This approach predicts the kinematic evolution of an orogenic belt in response to a change in material distribution. In this view, external (e.g. climate) and internal (e.g. rock durability/internal and basal friction) factors determine whether the mountains either propagate outward (from the rear of the wedge towards the foreland) to reduce the taper, or deform internally (e.g. by out-of-sequence or synchronous thrusting, duplexing) to rebuild taper (Carrapa, 2009; DeCelles and Mitra, 1995; Willett, 1999). In order to better understand the potential relationships between tectonics and climate during mountain building, as well as to evaluate the mechanisms driving the outward growth 
of an orogenic wedge, it is therefore crucial to determine the timing of the deformation within mountain belts (DeCelles and Mitra, 1995; Horton, 1999; Lease et al., 2016). However, these space-time datasets are sometimes poorly resolved due to the lack of detailed geologic information over often remote and inaccessible orogenic wedges. Moreover, although specific predictions of how climate, internal structures and geodynamics change in response to tectonic and climatic forcing have been made through analog and numerical models (Kohn, 2008; Malavieille, 2010; Malavieille et al., 2016; Stockmal, 1983; Whipple, 2009), more geologic examples are needed to evaluate these predictions.

The upward and outward growth of the Tibetan plateau represents a typical case where addition of crustal material has outpaced its removal (Fig. 1). Numerous studies have shown that mountain building processes in the eastern and southern margins of the Tibetan plateau can be reconciled with the critical taper theory (Corfield and Searle, 2000; DeCelles et al., 2001; Hubbard and Shaw, 2009; Hubbard et al., 2010; Whipple, 2009). These studies further argued that climate has significantly influenced the tectonic and structural evolution of mountain ranges. On the northeastern margin of the Tibetan plateau, although lines of evidence have suggested the northward growth of the Qilian Shan intra-continental wedge (northern Qilian Shan in particular) during the Cenozoic (Fig. 1a), the onset of deformation of ranges in the southern Qilian Shan is ambiguous and the driving mechanisms of the outwardgrowth process in the Qilian Shan are still highly debated (Bovet et al., 2009; Burchfiel et al., 1989; Craddock et al., 2011; Craddock et al., 2010; Craddock et al., 2014; Duvall et al., 2013; Métivier et al., 1998; Meyer et al., 1998; Ritts et al., 2004; Wang et al., 2017b; Yin et al., 2002; Yuan et al., 2011; Zhang et al., 2012a; Zheng et al., 2010; Zheng et al., 2017; Zheng et al., 2013b; Zhuang et al., 2011a; Zhuang et al., 2011b). In particular, while the tectonic and structural evolution of the Qilian Shan system remains to be fully explored and understood, 
little is known about the interaction between climate, erosion and deformation pattern in the range.

The driving mechanism of outward growth of mountain belts and the role played by climate during the mountain building process are difficult to assess without detailed constraints on the evolution of the orogenic wedge in the context of local climate evolution. In this study, we carry out provenance analysis and provide detrital zircon $\mathrm{U}-\mathrm{Pb}$ geochronological data, well log data, as well as seismic profiles obtained from the QaidamQilian region, to understand the source to sink relationship between Qilian Shan and adjacent basins and further pin down the of deformation of ranges in the southern Qilian Shan (Fig. 1). The structural evolution compared with evidence of local climate change reveals that the Cenozoic growth of the northeastern margin of the Tibetan plateau obeys critical-taper wedge theory, with the tectonic evolution of Qilian Shan being integrally tied to the climate evolution in this region. This study highlights that the Cenozoic evolution of northern Tibetan plateau cannot be clearly evaluated without understanding of how the climate may have controlled or at least modulated the kinematic history.

\section{Geological Setting}

\subsection{The Qilian Shan}

Defining the northeastern boundary of the modern Tibetan plateau, the Qilian Shan (at $>4000$ meters high on average) occupies a transition zone between the high elevation plateau and the adjacent low-elevation North China Craton to the northeast (Fig. 1)(Bovet et al., 2009; Cheng et al., 2019b; Lease, 2014; Yin and Harrison, 2000; Zuza et al., 2016). The Qilian Shan is bordered by the Qaidam basin to the south, the Hexi Corridor to the north, and bounded by the lithospheric-scale sinistral strike-slip ATF to the west (Fig. 1). Left-lateral displacement along the ATF has accommodated hundreds of kilometers of the postcollisional convergence between India and Asia, although the estimates of its total offset vary 
between ca. $300 \mathrm{~km}$ and ca. $500 \mathrm{~km}$ (Chen et al., 2002; Cheng et al., 2015a; Cheng et al., 2015b; Cowgill et al., 2003; Ritts and Biffi, 2000; Yin et al., 2002; Yue and Liou, 1999; Yue et al., 2001).

The Qilian Shan consists of a series of subparallel NW-SE striking ranges that grow on folds, thrusts or strike-slip faults accommodating the northward motion of the Tibetan plateau (Allen et al., 2017; Cheng et al., 2019b; George et al., 2001; Meyer et al., 1998; Yin et al., 2002; Yuan et al., 2013; Zhang et al., 2017; Zheng et al., 2017; Zheng et al., 2013a; Zhuang et al., 2011a; Zhuang et al., 2011b; Zuza et al., 2016; Zuza et al, 2018a; Zuza et al., 2017) (Fig. 1). According to the known Cenozoic kinematics of the Qilian Shan, the belt could have been divided in two units, namely the Northern Qaidam Thrust Belt to the south and the Qilian Shan Thrust Belt (or Qilian Shan- Nan Shan Thrust Belt) to the north (Wu et al., 2016; Zuza et al., 2018b). Based on the pre-Cenozoic crustal lithologies, as well as the occurrence of suture zones within the range, the belt has been divided into four terranes, namely the northern Qilian Shan (NQS), the central Qilian Shan (CQS), the southern Qilian Shan (SQS), and the North Qaidam Thrust Belt (Bovet et al., 2009; Gehrels et al., 2003; Ritts et al., 2004). On the southern side of Qilian Shan, provenance studies have been used to infer that the North Qaidam Thrust Belt was exhumed during Eocene to Oligocene time, serving as the source region for the clastic material deposited in both the Hexi Corridor to the north and the Qaidam basin to the south (Bovet et al., 2009; Yin et al., 2008a; Zhuang et al., 2011b). To the north, some low-temperature thermochronology studies and provenance analysis have revealed the northward younging of the time of activation of the successive sub-ranges, suggesting a progressive northward propagation of fold thrust belt in the central and northern Qilian Shan from Miocene to Pliocene (Bovet et al., 2009; Cheng et al., 2019b; George et al., 2001; Wang et al., 2016a; Yu et al., 2019; Zhang et al., 2017; Zheng et al., 2010; Zheng et al., 2017). In addition, some studies also advocate for an early Cenozoic onset of deformation in 
the North Qaidam Thrust Belt and NQS (He et al., 2017; He et al., 2018; Jolivet et al., 2001; Li et al., 2019). However the mountain building processes in the SQS is not well-constrained. A detailed discussion on the Cenozoic deformation in the Qilian Shan region is given in section 5.4.1.

\subsection{The Qaidam and Suganhu basins}

Situated on the northern edge of the Tibetan Plateau, the triangle-shaped Qaidam basin is surrounded by the ATF to the northwest, the Qilian Shan to the northeast, and the Eastern Kunlun Shan to the south (Fig. 1). Surveys for petroleum exploration indicate that the Qaidam basin contains as thick as $\sim 14 \mathrm{~km}$ Cenozoic sediments in some places (Cheng et al., 2016a; Cheng et al., 2018; Cheng et al., 2016b; Meng and Fang, 2008; Xia et al., 2001; Yin et al., 2008a; Yin et al., 2008b; Yin et al., 2007). The Cenozoic deposits within the basin are subdivided into eight lithostratigraphic units (Fig. 2). From the oldest to the youngest these units are (followed by the symbol for each unit): (1) the Lulehe Formation, $E_{1+2} l ;(2)$ the Lower Xiaganchaigou Formation, $\mathrm{E}_{3}{ }^{1} \mathrm{xg}$; (3) the Upper Xiaganchaigou Formation, $\mathrm{E}_{3}{ }^{2} \mathrm{xg}$; (4) the Shangganchaigou Formation, $\mathrm{N}_{1} \mathrm{sg}$; (5) the Xiayoushashan Formation, $\mathrm{N}_{2}{ }^{1} \mathrm{xy}$; (6) the Shangyoushashan Formation, $\mathrm{N}_{2}{ }^{2}$ sy; (7) the Shizigou Formation, $\mathrm{N}_{2}{ }^{3} \mathrm{~s}$; and (8) the Qigequan Formation $\left(\mathrm{Q}_{1} \mathrm{q}\right)$. The symbols $\mathrm{E}_{1+2} 1, \mathrm{E}_{3}{ }^{1} \mathrm{xg}, \mathrm{E}_{3}{ }^{2} \mathrm{xg}, \mathrm{N}_{1} \mathrm{sg}, \mathrm{N}_{2}{ }^{1} \mathrm{xy}, \mathrm{N}_{2}{ }^{2} \mathrm{sy}, \mathrm{N}_{2}{ }^{3} \mathrm{~s}$, and $\mathrm{Q}_{1} \mathrm{q}$ are the codes for each unit. The exact depositional ages of the above-mentioned formations are still controversial (Chang et al., 2015; Cheng et al., 2018; Fang et al., 2007; Ji et al., 2017; Ke et al., 2013; Lu and Xiong, 2009; Wang et al., 2017b; Yin et al., 2007; Zhuang et al., 2011b), with the two different age models shown in Figure 2. Outcrop and subsurface data (including seismic and drill cores data) reveal that the Cenozoic deposits are predominately composed of alluvial, fluvial, and lacustrine deposits (Cheng et al., 2016a; Cheng et al., 2018; Cheng et al., 2019a; Cheng et al., 2016b; Meng and Fang, 2008; Wang et al., 2006; Wu et al., 2012a; Wu et al., 2012b; Xia et al., 2001; Zhang et al., 2013; Zhuang et al., 2011b). 
Forming the largest depression within the Qilian Shan, the Suganhu basin is bordered by the Southern Qilian Shan to the north and the North Qaidam Thrust Belt to the south (Fig. 1b). As demonstrated by seismic profiles, drill cores, and sequence stratigraphy studies, the Suganhu basin is filled with $\sim 800 \mathrm{~m}$ thick Jurassic and $>1000 \mathrm{~m}$ thick Cenozoic continental terrestrial sediments (Fig. 2), recording the growth of the Qilian Shan. Using correlation with the strata in the Qaidam basin, the Cenozoic sequence in the Suganhu basin, mainly composed of alluvial and fluvial deposits, are subdivided into eight lithostratigraphic units (Meng and Fang, 2008) (Fig. 2).

\section{Methods}

In this study, we provide detrital zircon U-Pb geochronological data, and well log data that were obtained from the Qaidam-Qilian region to describe the source to sink relationship between the Qilian Shan and adjacent basins. Seismic profiles from the Qaidam and Suganhu basins are also provided to pin down the onset of deformation of sub-ranges in the southern Qilian Shan. Combined with the evidence for local climate change and ages of the onset of deformation of sub-ranges in the entire Qilian Shan, we propose a new scenario, interpreting the behavior of the Qilian Shan wedge evolution in terms of a long-term trends wedge taper in response to climate change.

\subsection{U-Pb detrital zircon geochronology}

We collected a total of 14 sandstone samples from drill cores. Samples P-E ${ }_{1+2}, \mathrm{SS}_{3}-\mathrm{E}_{3}{ }^{1}$, SS3- $\mathrm{E}_{3}{ }^{2}, \mathrm{SS} 3-\mathrm{N}_{2}{ }^{1}-\mathrm{b}, \mathrm{SS} 3-\mathrm{N}_{2}{ }^{1}-\mathrm{t}, \mathrm{SS} 3-\mathrm{N}_{2}{ }^{2}, \mathrm{SS} 3-\mathrm{N}_{2}{ }^{3}$ and SS3-Q $\mathrm{Q}_{1}$ were obtained from cores in the NE Qaidam basin, while samples $\mathrm{S} 3-\mathrm{E}_{1+2}, \mathrm{~S} 3-\mathrm{E}_{3}{ }^{1}, \mathrm{~S} 3-\mathrm{E}_{3}{ }^{2}, \mathrm{~S} 3-\mathrm{N}_{1}, \mathrm{~S} 3-\mathrm{N}_{2}{ }^{1}$ and $\mathrm{S} 3-\mathrm{Q}_{1}$ were collected from a drill core in the Suganhu basin (Figs. 1-2). Zircon U-Pb ages cumulative probability distribution for each sample is shown in Fig. 3. Representative CL images and U$\mathrm{Pb}$ concordia diagrams for zircon grains of each sample are shown in Fig. A2 and Fig. A3 in 
Appendix A, respectively. Detailed analytical methods are provided in Appendix A. U-Pb isotopic ages with errors and related raw data are listed in full in Appendix B.

\subsection{Subsurface data}

We integrated high-quality seismic profiles with drill core data from both the Qaidam and the Suganhu basins to describe the tectonic history of this region. The 2D seismic profiles $\mathrm{AA}^{\prime}$ (Fig. 4a-4b) and BB' (Fig. 4c-4d) are situated in the Suganhu basin, while the 3D seismic profiles CC' (Fig. 5f and 5h) and DD' (Fig. 5g and 5i) are located in the NE Qaidam basin. The 3D seismic profile EE' (Fig. 6e-6h) was obtained from the SW Qaidam basin. By using the 3D seismic data, two-way travel time seismic slices from the NE Qaidam basin (Fig. 5e) and SW Qaidam (Fig. 6d) were generated to show the fault geometry. Seismic data were provided by the Qinghai Oilfield, PetroChina and were interpreted using the SMT Kingdom software. We also used drill core data provided by the Qinghai Oilfield, PetroChina and a compilation of published stratigraphic data to document the sedimentary characteristics of the Paleogene strata within the Qaidam basin (Figs. 5a-5d, 6a-6c and A1).

\section{Results}

\subsection{Detrital zircon morphology, origin and $\mathrm{U}-\mathrm{Pb}$ geochronology}

The detrital zircons from all the samples are dominated by oscillatory zoning in CL images (Fig. A2), indicative of predominant magmatic origins (Corfu et al., 2003; Hoskin and Black, 2000). Over $80 \%$ of those grains are large $(80-200 \mu \mathrm{m})$ with euhedral to abraded shapes. 1358 out of 1407 detrital zircons display high $\mathrm{Th} / \mathrm{U}$ ratios from 0.10 to 3.94 , confirming a largely magmatic origin (Corfu et al, 2003; Hoskin and Black, 2000). The statistical U-Pb geochronology data for each of the samples are listed in Table 1.

\subsection{Stratigraphy and sedimentary characteristics of the Lulehe to Xiaganchaigou formations}


Based on analysis of 9 drill cores and additional well-log data provided by the Qinghai Oilfield, PetroChina, two well correlations trending approximately parallel to the Qilian Shan and Eastern Kunlun, respectively, were established (Figs. 5a and 6a). Images of typical facies represented in drill core samples are shown in Fig. A1 in Appendix A. The purpose of this stratigraphic description is to present the facies shifts across the basin interior. Combining this observation with the information on deformation obtained from the seismic profiles shown in the following section, we will discuss the evolution of the Qaidam basin and the tectonic-climate interactions in the Qilian Shan region.

\subsubsection{NE Qaidam basin}

The lower part of the successions (in Well 1 to Well 5) is defined as the Lulehe Fm., while the upper part corresponds to the Xiaganchaigou Fm. (Fig. 5a). The Lulehe Fm. is mainly composed of brownish-red coarse-grained conglomerate intercalated with sandstone and claystone (Fig. A1a-A1b). The deposits are structureless, and the boulder- to cobblesized clasts are angular to sub-angular and poorly sorted with mud matrix, probably indicative of debris flows within a proximal alluvial fan depositional environment (Sun et al, 2016; Zou et al., 2015). Different from the Lulehe Fm., the observed Lower Xiaganchaigou Fm. succession is mainly composed of greyish thickly bedded coarse- to medium-grained pebbly sandstone interbedded with brownish thickly bedded siltstone and granule-pebble conglomerate (Figs. 5a, A1c-A1h). Graded bedding, planar (or trough) cross-bedding, flat to low-angle cross-stratified sandstone, and erosional broad to shallow scours are well developed (Fig. A1c-A1h), probably indicative of a braided river system (Fig. A1c-A1h) (Sun et al., 2016; Zou et al., 2015).

Based on the facies interpretation dataset provided by the Qinghai Oilfield, PetroChina (Zou et al., 2015), the Lulehe, Lower Xiaganchaigou and Shangganchaigou formations exhibit a distinct basin-ward shift of lithofacies associations, from proximal alluvial fan 
facies to distal lacustrine facies in plan view (Fig. 5b-5d). Vertically, from the deposition of the Lulehe Fm. to Shangganchaigou Fm., the coarse deposits (alluvial fan and braided river deposits) retrograded northwards (Fig. 5b-5d). The alluvial fan facies of the Lulehe Fm. gradually evolved upwards to braided river facies in the Lower Xiaganchaigou and Shangganchaigou formations. This retrogradation of alluvial-fluvial facies relative to the North Qaidam Thrust Belt could either result from decreased tectonic deformation in the North Qaidam Thrust Belt and SQS or due to the northward expansion of the basin drainage area (Fig. 5a-5d).

\subsubsection{SW Qaidam basin}

In Well 6 to Well 9 in the Qaidam basin, the lower part of the successions is defined as the Lulehe Fm., while the upper part corresponds to the Lower Xiaganchaigou Fm. (Fig. 6a). In this region, the lower part of the Lulehe Fm. is mainly composed of thickly bedded brownish calcareous siltstone and silty shale interbedded with brownish red thinly bedded fine-grained sandstone and conglomerate, while the upper part of the Lulehe Fm. mainly consists of thickly bedded carbonate-rich silty shale interbedded with thinly bedded finegrained sandstone. Planar cross-bedded siltstone, thinly bedded to laminated shale, enrichment of organic matter, as well as the bioturbation are suggestive of a low-energy delta plain to delta front depositional environment (Zhang et al., 2013) (Figs. 6a, A1i). The lower part of the Lower Xiaganchaigou Fm. is mainly composed of greyish sandstone and siltstone intercalated with interbedded thinly bedded claystone and pebble-cobble conglomerate (Fig. A1j-A11), while the middle and upper parts of the Lower Xiaganchaigou Fm. are dominated by greyish thickly bedded calcareous shale intercalated with thinly bedded siltstone (Figs. 6a, A1m-A1n). In addition, the middle and upper parts of Lower Xiaganchaigou Fm. in this region are marked by high natural gamma ray values, indicative of a high shale content $(\mathrm{Mu}$, 2002). The well-sorted sand, planar-bedded to rippled sandstone, laminated siltstone, 
abundance organic matter and presence of bioturbation in the lower part of Lower Xiaganchaigou Fm. suggest a low-energy delta front setting (Mu, 2002). Varved calcareous shale, thinly bedded limestone and marl as well as the soft-sediment deformation in the middle and upper parts of Lower Xiaganchaigou Fm. suggest a marginal lacustrine environment.

According to the facies dataset interpreted by the Qinghai Oilfield, PetroChina (Fig. 6b6c) (Zhang et al., 2013), the Lulehe and Lower Xiaganchaigou formations exhibit distinct basin-ward shift of lithofacies association, from delta plain facies to lacustrine facies in plan view. Chronologically, during the period covered by those two formations, the deltaic front deposits retrograded southwestwards relative to the Eastern Kunlun Shan (Fig. 6b-6c). In particular, previous existing deltaic facies in Lulehe Fm. evolved upwards to and lacustrine facies in the Lower Xiaganchaigou Fm. We infer that this retrogradation of deltaic deposits, was related to the expansion lacustrine facies in the SW Qaidam basin during that period of time (Fig. 6b-6c).

\subsection{Seismic data}

Seismic profiles AA' and BB' (Fig. 4) are situated in the central part of the Suganhu basin, running from the northern front of the North Qaidam Thrust Belt to the southern flank of the SQS (Fig. 1b). Based on the truncation of prominent reflectors, three major boundary faults, namely Fs1, Fs2 and Fs3, can be identified. Fs1 and Fs3 dip south and root into the North Qaidam Thrust Belt, while Fs2 dips to the north in profile AA' and to the south in profile BB' (Fig. 4). Although strata on each side of Fs1 and Fs3 consist of the same Cenozoic units, the thickness of each unit is quite different showing obvious stratigraphic separation. The thickness of the Lulehe, Lower Xiaganchaigou, Upper Xiaganchaigou and Shangganchaigou formations taper towards the Fs1 and Fs3, forming growth structures on both side of the faults (Fig. 4). In the northern part of the Suganhu basin, the thickness of the 
Lulehe, Lower Xiaganchaigou, Upper Xiaganchaigou and Shangganchaigou formations within the hanging wall of Fs2 decreases towards the faults (Fig. 4b and 4d). Based on growth strata, thrust faults in the Northern Qaidam Thrust Belt and SQS initiated during the deposition of the Lulehe Fm. and was active during the deposition of the Lower Xiaganchaigou, Upper Xiaganchaigou and Shangganchaigou formations.

Seismic profiles CC' and DD' (Fig. 5e) are located about $60 \mathrm{~km}$ southeast of Lenghu (Fig. 1) and run from the southern flank of the North Qaidam Thrust Belt to the central NE Qaidam basin. The tectonic pattern in this region is characterized by two reverse faults (namely the Tuonan-Pingdong fault and Sainan fault) and the cover-sequence only consists of Cenozoic strata (Fig. 5). Both faults dip north, rooting into the North Qaidam Thrust Belt. Like in profiles AA' and BB', the thickness of the Lulehe and Lower Xiaganchaigou formations varies across the faults and the faults show obvious stratigraphic separation. In particular, growth strata developed in the hanging wall of the Tuonan-Pingdong fault and Sainan fault tapers towards the faults (Fig. 5h-5i). We thus propose that the Tuonan-Pingdong and Sainan faults initiated during the deposition of the Lulehe Fm. and continued to be active during the deposition of the Lower Xiaganchaigou Fm, indicating crustal shortening within the North Qaidam Thrust Belt.

Seismic profile EE' (Fig. 6; See location on Fig. 3) is situated in the SW Qaidam basin, running from the northern flank of the Eastern Kunlun Shan to the Altyn Tagh Shan. Several basement-involved faults offset the Lulehe Fm. and the Lower Xiaganchaigou Fm. strata. Cheng et al. (2014) attributed these offsets to post-Miocene left-lateral strike-slip motion of the basement-involved faults, based on isopach map analysis and 3D seismic profile interpretation. These post-sedimentation tectonics should thus not be taken into account to describe the Paleogene evolution of the SW Qaidam basin. Our newly acquired 3D seismic profile shows successive westward onlap of the Lulehe and Lower Xiaganchaigou formations 
(Fig. 6e-6h), suggesting a progressive expansion of the Qaidam basin to the west from the deposition of the Lulehe Fm. to the Lower Xiaganchaigou Fm.

\section{Discussion}

\subsection{Sediment provenance}

To better constrain the provenance area of the samples, we compiled zircon $\mathrm{U}-\mathrm{Pb}$ ages available from basement rocks of the two potential source regions, namely the SQS and the North Qaidam Thrust Belt (Cheng et al., 2016b; Cheng et al., 2017; Yin et al., 2008a) (Fig. 3a-3c). The zircon (including both zircons from individual plutonic and inherited zircons) U$\mathrm{Pb}$ ages from the basement of the SQS terrane can be divided into four populations with a major early Paleozoic age group (peak at ca. $469 \mathrm{Ma}$ ) and three additional populations at ca. 2713-2259 Ma, ca. 1867-1128 Ma and ca. 1030-744 Ma (Fig. 3b). Different from the SQS, the zircon (including zircons from individual plutonic and inherited zircons) $\mathrm{U}-\mathrm{Pb}$ age spectrum of the North Qaidam Thrust Belt basement is characterized by an obvious decrease in Archean-Paleoproterozoic ages (from ca. $26 \%$ in the SQS to ca. $8 \%$ in the North Qaidam Thrust Belt) and a significant increase in the Permo-Triassic age (peak age at ca. $239 \mathrm{Ma}$ ) (from $<1 \%$ in the SQS to ca. $14 \%$ in the North Qaidam Thrust Belt). Some Neoproterozoic plutons are also present with a zircon U-Pb age group between $\sim 1077 \mathrm{Ma}$ and $\sim 742 \mathrm{Ma}$ (Fig. 3c). In addition, early Paleozoic granitoid plutons dispersed across the North Qaidam Thrust Belt with a peak zircon U-Pb age at ca. $439 \mathrm{Ma}$, again showing an early Paleozoic age signature.

To understand the similarities/dissimilarities between the zircon $\mathrm{U}-\mathrm{Pb}$ distribution of individual samples and the zircon U-Pb pattern of the basement of the SQS and North Qaidam Thrust Belt, we adapted the multidimensional scaling (MDS) map. This map that was developed to create a spatial visualization to determine the misfit between age distributions using the Kolmogorov-Smirnov (KS) test as the dissimilarity measure 
(Vermeesch, 2013). As shown in Figure 3r and 3s, two groups of similarly sourced samples can be identified: (1) Samples P-E $\mathrm{E}_{1+2}, \mathrm{SS} 3-\mathrm{E}_{3}{ }^{1}, \mathrm{SS} 3-\mathrm{E}_{3}{ }^{2}, \mathrm{SS} 3-\mathrm{N}_{1}, \mathrm{SS} 3-\mathrm{N}_{2}{ }^{1}-\mathrm{b}, \mathrm{SS} 3-\mathrm{N}_{2}{ }^{1}-\mathrm{t}, \mathrm{SS} 3-$ $\mathrm{N}_{2}{ }^{2}, \mathrm{SS} 3-\mathrm{N}_{2}{ }^{3}$ and SS3-Q ${ }_{1}$, all displaying a zircon assemblage mainly consisting of early Paleozoic and Permian-Triassic ages together with a few Precambrian ages, (2) Samples S3$\mathrm{E}_{1+2}, \mathrm{~S} 3-\mathrm{E}_{3}{ }^{1}, \mathrm{~S} 3-\mathrm{E}_{3}{ }^{2}, \mathrm{~S} 3-\mathrm{N}_{1}, \mathrm{~S} 3-\mathrm{N}_{2}{ }^{1}$ and $\mathrm{S} 3-\mathrm{Q}_{1}$, which are dominated by a significant amount of Neoproterozoic and Archean-Mesoproterozoic ages with additional early Paleozoic and Late Paleozoic-Mesozoic populations. Given that all the samples in Group 2 were collected from the Suganhu basin, the similarity in detrital zircon age distribution between Group 2 samples and the basement of the SQS indicates that the SQS served as the dominant source region for the Suganhu basin. However, all samples in Group 1 were collected from the NE Qaidam basin. Their detrital zircon age distributions are comparable to that of the basement of the North Qaidam Thrust Belt, designating this range as the main sediment source area.

In particular, in the NE Qaidam basin, the Lulehe Fm. sample $\left(\mathrm{P}-\mathrm{E}_{1+2}\right)$ yield a major age peak at ca. $425 \mathrm{Ma}$ with a minor age peak at ca. $806 \mathrm{Ma}$ (Fig. 3q), whereas the overlying

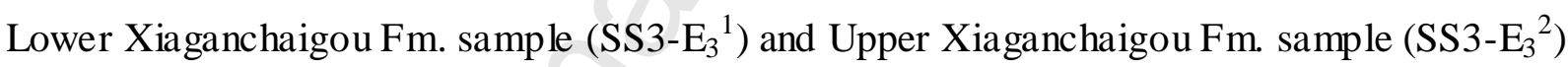
contain zircons of ca. 2525-2504 Ma, 2149-1597 Ma, 1151-630 Ma, 436-405 Ma and 243$229 \mathrm{Ma}$ (Fig. 3o-3p). The new Mesozoic age peak, absent in the Lulehe Fm. sample, is associated with an increase in the proportion of Archean-Paleoproterozoic ages (from 14\% to $\sim 19 \%$ ). Given the limited Archean-Paleoproterozoic zircon $\mathrm{U}-\mathrm{Pb}$ ages reported from the North Qaidam Thrust Belt basement (Fig. 3a, 3c), we propose that the SQS that contains a large reservoir of Archean-Paleoproterozo ic zircon U-Pb ages likely became an additional source for the NE Qaidam basin during the deposition of the Lower Xiaganchaigou to the Upper Xiaganchaigou formations. This emergence of an increase in the proportion of PermoTriassic and Archean-Paleoproterozoic ages could also result from changes in the local drainage organization or from the ultimate exposure of buried Permo-Triassic and Archean- 
Paleoproterozoic plutons (Zhang et al., 2012b; Zhang et al., 2016). In addition, Permian, Triassic and Cretaceous sedimentary rocks also show a similar zircon-age population (Zuza et al., 2018b), indicating potential pre-Cenozoic sediment recycling. However, our preferred interpretation is further supported by well log observations in the NEQaidam basin (Fig. 5b5d) that shows upward lithofacies association transition (from alluvial deposits in the Lulehe Fm. to braided river deposits in the Lower Xiaganchaigou Fm.) and northward retrogradation of alluvial-fluvial deposits at that time. We therefore suggest that the North Qaidam Thrust Belt was the sole source of clastic material for the NE Qaidam basin during the deposition of the Lulehe Fm., while both the North Qaidam Thrust Belt and the SQS contributed during the deposition of the Lower Xiaganchaigou to Upper Xiaganchaigou Fms.

Although zircon $\mathrm{U}-\mathrm{Pb}$ age distribution of the samples collected from the Xiayoushashan to the Qigequan formations (SS3- $\left.\mathrm{N}_{2}{ }^{1}-\mathrm{b}, \mathrm{SS} 3-\mathrm{N}_{2}{ }^{1}-\mathrm{t}, \mathrm{SS} 3-\mathrm{N}_{2}{ }^{2}, \mathrm{SS} 3-\mathrm{N}_{2}{ }^{3}, \mathrm{SS} 3-\mathrm{Q}_{1}\right)$ are still dominated by early Paleozoic zircons (with ca. 26\%-ca. $61 \%$ of total, peaks ranging from ca. $435 \mathrm{Ma}$ to ca. $419 \mathrm{Ma}$ ) and Late Paleozoic to Mesozoic zircons (with ca. 21\%-57\% of total, peaks ranging from ca. $262 \mathrm{Ma}$ to ca. $244 \mathrm{Ma}$ ), Archean-Paleoproterozo ic zircons become scarce (ca. 3\%-14\% of total) (Fig. 3j-3n). Given that seismic profiles, low-temperature thermochronology as well as sedimentologic studies show that crustal shortening in the North Qaidam Thrust Belt intensified since the deposition of the Xiayoushashan Fm. (Bush et al., 2016; Cheng et al., 2016b; Jolivet et al., 2001; Yin et al., 2008a; Zhuang et al., 2011b), we suggest that increased growth of the North Qaidam Thrust Belt may have cut off the link between the Archean-Paleoproterozoic source rocks in SQS and the depositional area in the NE Qaidam basin. In addition, a decrease in precipitation usually causes a decrease in climatically driven erosion rate (Zheng et al., 2010), resulting in less materials input to a depositional basin. Thus, the regional intensification of the aridity at that time (Dettman et al., 
2003; Li et al., 2016; Zhuang et al., 2011a) would also lead to the increased unbalance of materials between the source and sink.

All the samples from the Suganhu basin contain abundant Archean-Paleoproterozoic zircons $\mathrm{U}-\mathrm{Pb}$ ages, indicative of material sourcing from the basement plutonic rocks and/or pre-Cenozoic sedimentary rocks in the SQS. From the Lulehe Fm. upwards to the Shangganchaigou Fm. $\left(\mathrm{S} 3-\mathrm{E}_{1+2}, \mathrm{~S} 3-\mathrm{E}_{3}{ }^{1}, \mathrm{~S} 3-\mathrm{E}_{3}{ }^{2}\right.$, and $\left.\mathrm{S} 3-\mathrm{N}_{1}\right)$, the zircon age populations gradually become more diverse (Fig. 3f-3i). Especially, the number of Late Paleozoic to Mesozoic zircons that are rare in the Lulehe to Upper Xiaganchaigou formations (samples $\mathrm{S} 3-\mathrm{E}_{1+2}, \mathrm{~S} 3-\mathrm{E}_{3}{ }^{1}$, and $\mathrm{S} 3-\mathrm{E}_{3}{ }^{2}$ ) largely increases in the Shangganchaigou Fm. (sample $\mathrm{S} 3-\mathrm{N}_{1}$ ). Given that the Late Paleozoic to Mesozoic zircons are the fingerprint of the North Qaidam Thrust Belt source, we propose that the source region of the Suganhu basin gradually expanded until both the North Qaidam Thrust Belt and the SQS contributed material during the deposition of the Shangganchaigou Fm. However, the Late Paleozoic to Mesozoic zircons became scarce in the Xiayoushashan to Qigequan Fm. samples (Fig. 3e-3d) (samples $\mathrm{S} 3-\mathrm{N}_{2}{ }^{1}$ and S3-Q 1 ). We infer that increased deformation (Cheng et al., 2016b; Jolivet et al., 2001; Yin et al., 2008a) and regional aridification (Dettman et al., 2003; Li et al., 2016; Zhuang et al., 2011a) strongly modified the drainage system in this region, finally preventing some of the sediment derived from the North Qaidam Thrust Belt from reaching the sampling site (central Suganhu basin). Therefore, the post-Xiayoushashan Fm. deposits are likely derived from local sources and the recycling of deformed Lulehe to Shangganchaigou formation deposits or even Permian to Cretaceous sedimentary rocks.

\subsection{Paleoclimate in the Qaidam basin and Qilian Shan during the Cenozoic}

Despite few sporadically distributed early to middle Eocene dust deposits that have been reported in the Xining and Xorkol basins (Li et al., 2018; Licht et al., 2016; Lu et al., 2019), the paleoclimate in the NE Tibetan plateau by that time has not yet been clearly established. 
Recent studies reported fossil records of Paleoschizothorax, an extinct genus of freshwater fish living in warm water environments, and Podocarpium podocarpum, with thermophilous and moisture-loving habit, have been found in the lacustrine deposits of the Shangganchaigou Fm. in the Qaidam basin, indicating both wetter and warmer conditions compared to modern climate (Yan et al., 2018; Yang et al., 2018). Despite fluctuations, a general decrease in the average lacustrine carbonate $\delta^{18} \mathrm{O}$ values from the Lower Xiaganchaigou Fm. to the Shangganchaigou Fm. has been reported throughout the Qaidam basin (Fig. 8a-8g) (Li et al., 2016; $\mathrm{Li}$ et al., 2017; Mao et al., 2014; Rieser et al., 2009). The $\delta^{18} \mathrm{O}$ value of the lacustrine limestone and marl are controlled by multiple factors, including the isotopic signature of surface water and groundwater flowing into the lake, evaporation from the lake, the temperature of carbonate precipitation. Thus, local paleo-hydrological changes and regional climate changes could affect the lacustrine carbonate $\delta^{18} \mathrm{O}$ values ( $\mathrm{Li}$ et al., 2016). Given that lithofacies, seismic profiles, and detrital zircon geochronology datasets support a basin-scale expansion of the Qaidam basin lacustrine deposits and drainage area during the deposition of the Lower Xiaganchaigou Fm. to the Shangganchaigou Fm., we suggest that the basin-scale negative $\delta^{18} \mathrm{O}$ shift of marls/limestones at that time reflects a decrease in evaporation of lake water, probably related to regional climate change toward wetter conditions.

The occurrence of Oligocene to early Miocene aeolian strata in western China has been used to argue for aridification of Central Asia. Although lacking aeolian records, some advocate the initial late Eocene to Oligocene aridification in the northeastern Tibetan plateau based on the disappearance of the Paleogene playa lake systems, as well as shifts in lithofacies and pollen records in the Xining basin (Bosboom et al., 2014; Dupont-Nivet et al., 2007). In the northern Junggar basin, the earliest aeolian deposition was dated at $24 \mathrm{Ma}$ (Sun et al., 2010). In the southwestern Tarim basin, isolated dunes were dated between 26.7 Ma and 22.6 Ma (Zheng, 2016; Zheng et al., 2015). Wang et al. (2014) proposed that regional 
aridification started around $23 \mathrm{Ma}$ based on the intermittent aeolian accumulation in the Pamir-Tian Shan convergence zone. In the Lanzhou basin (NE Tibetan plateau), the onset time of aeolian accumulation has been dated at ca. $26 \mathrm{Ma}$ (Zhang et al., 2014). Further to the east, some 25-22 Ma aeolian successions have also been reported in the western part of the Chinese Loess Plateau (Guo et al., 2002; Qiang et al., 2011). The regional cooling and aridification record is also found in the hydrocarbon basins (e.g. Bohai basin) in eastern China (Liu et al., 2011b). Based on both regional evidence and global cooling at this time (Zachos et al., 2001), we suggest that the aridification of the Qaidam basin and Qilian Shan possibly began in the Oligoene to early Miocene.

The subsequent sustained aridification in the Qilian Shan during the middle Miocene could be inferred from sedimentary records in the surrounding basins and ranges. These records include the positive shift in the $\delta^{18} \mathrm{O}$ values from the fluvial and lacustrine carbonates in the Linxia basin (Dettman et al., 2003), in the southern side of the Qilian Shan (Zhuang et al., 2011a), and in the Qaidam basin (Li et al., 2016) since the middle Miocene. Meanwhile, the appearance of aeolian deposits in the Lanzhou basin (Zhang et al., 2014) and the Taklimakan desert (Heermance et al., 2018) to the west also support the reginal aridification in the western China since the middle Miocene.

\subsection{The Cenozoic evolution of the Qaidam basin: from expansion to isolation}

5.3.1 Paleogene to early Neogene expansion of the Qaidam basin (Lulehe Fm. to Shangganchaigou Fm.)

Our stratigraphic (Fig. 5) and detrital zircon geochronological record (Fig. 3) imply a northward retrogradation of the coarse deposits in the NEQaidam basin, indicative of a northward expansion of the basin drainage area. To the south, drill cores and seismic profiles also show a southwestward retrogradation of the deltaic facies and a widening of lacustrine deposition in the SW Qaidam basin, consistent with previous provenance analysis (Cheng et 
al., 2016a). In addition, the compilation of all the detrital zircon U-Pb geochronology data available on the Cenozoic strata in the Qaidam basin display an increasing proportion of Mesozoic to Late Paleozoic and Precambrian ages (Bush et al., 2016; Cheng et al., 2016a; Cheng et al., 2016b; Wang et al., 2017b; Zhou et al., 2018), which reveals that potential source areas became much more diverse gradually from the Lulehe Fm., to Xiaganchaigou Fm. and to Shangganchaigou Fm. (Fig. 7). This increasing diversity of material sources may also reflect the expansion of the Qaidam basin drainage area during that period of time. Therefore, we propose that the Qaidam basin underwent basin-scale transgression during the Paleogene as drainage areas surrounding the basin expanded outward.

Offsets along the various thrust faults that root into the North Qaidam Thrust Belt and the SQS, as well as tapering growth strata within the hanging walls of those faults, indicate contractional deformation in the North Qaidam Thrust Belt and SQS regions during the deposition of Lulehe to Shangganchaigou formations. These observations are consistent with previously published subsurface and outcrop constraints (Bush et al., 2016; Cheng et al., 2016b; Yin et al., 2008a; Zhuang et al., 2011b). Under stable climate conditions, crustal shortening in orogenic belts usually triggers a basin-ward regression of facies, resulting basin-ward migration of shoreline environments (Glass and Wilkinson, 1980). Given the fact that the coarse deposits in the NE Qaidam basin progressively retrograded northward toward the range between the deposition of the Lulehe Fm. and that of the Shangganchaigou Fm., we infer that the climate played a significant role that overcame the topographic effects of simultaneous contractional tectonics in the NEQaidam basin, North Qaidam Thrust Belt and SQS and drove the northward expansion of the NE Qaidam basin drainage area.

As discussed in section 5.2, Qaidam basin and the Qilian Shan were in a less evaporative environment during the deposition of Lulehe Fm. to Shangganchaigou Fm., probably related to regional climate change toward wetter conditions. During this wetter climate period, 
increasing precipitation in the Qaidam basin and surrounding mountain belts would have contributed to the retrogradation of the shoreline. We thus deduce that wetter climate drove the expansion of both the Qaidam basin lake area and sedimentary source areas during the Paleogene (Fig. 8h-8i).

\subsubsection{Isolation of the Qaidam basin (Xiaganchaigou Fm. to the present)}

Our provenance analysis indicates a decrease in the diversity of detrital material sources feeding the NE Qaidam and Suganhu basins since the onset of deposition of the Xiayoushashan Fm. This suggests that the drainage systems previously linking the Qaidam basin to the hinterlands of the growing surrounding mountain belts were cut off (Cheng et al., 2016a; Cheng et al., 2016b; McRivette et al., 2019). Despite the depositional age of the Cenozoic strata within the basin remaining controversial, both age models argue for a Miocene basal age for the Xiayoushashan Fm. (Ji et al., 2017; Wang et al., 2017b), roughly coeval with the rapid exhumation episode revealed by low-temperature thermochronology in the surrounding mountain belts (Duvall et al., 2013; George et al., 2001; Jolivet et al., 2001; Qi et al., 2016a; Wang et al., 2006; Wang et al., 2017b; Yu et al., 2019). We thus infer that continued deformation along the margins of the basin and in the surrounding mountain belts result in the ultimate isolation of the Qaidam basin since the Miocene. On the other hand, observed regional aridification at that time (Dettman et al., 2003; Li et al., 2016; Zhang et al., 2014; Zhuang et al., 2011a) may also have contribute to the Miocene aridification and isolation of the Qaidam basin (Fig. 8i-8j).

\subsection{Qilian Shan wedge dy namics: implication for the climate-tectonic interplay in} the northem Tibetan plateau

\subsubsection{Cenozoic deformation in the Qilian Shan and Jiuquan basin}

As recent studies suggested (He et al., 2017; He et al., 2018), a growing number of studies show several cooling patterns that suggest pulses of exhumation, which can be tied to 
the deformation in the Qilian Shan. Despite a complex growth history, two significant observations persist: (1) the Qilian Shan experienced early Cenozoic deformation and (2) widespread Miocene deformation occurred across the Qilian Shan.

Given that India-Asia collision initiated during the early Cenozoic (Dupont - Nivet et al, 2010; Hu et al., 2015; Najman et al., 2010), it is possible that stress derived from the collision zone was transmitted rapidly at ca. 60-50 Ma to the northern and northeastern edge of the modern Tibetan plateau, or even to the Tian Shan range (Jolivet et al., 2010). However, it is also notable that most early Cenozoic deformation was distributed in the Northern Qaidam Thrust Belt and the SQS, rather than in the central or northern Qilian Shan regions (Bush et al., 2016; Cheng et al., 2016c; He et al., 2017; He et al., 2018; Jolivet et al., 2001; Qi et al., 2016a; Yin et al., 2008a; Zhuang et al., 2011b). For instance, fault offset and growth structures shown on seismic profiles imply that the deformation in the North Qaidam Thrust Belt initiated during the deposition of the Lulehe Fm. (Figs. 4-5)(Cheng et al., 2019a; Yin et al., 2008a). This is also supported by the initiation of basin subsidence along the southern flank of the Qilian Shan during the deposition of the Lulehe Fm. During that period, the Lulehe Fm. was characterized by thick basal conglomerates in the NE Qaidam and Suganhu basins (Fig. 2) (Cheng et al., 2019a; Yin et al., 2008a; Zhuang et al., 2011b). Seismic profiles in the Suganhu basin (Fig. 4) and provenance analysis shown in this study (Figs. 3 and 5) reveal that the deformation in the SQS also initiated during the deposition of the Lulehe Fm. Despite uncertainty in the basal age of the Lulehe Fm. (ca. $50 \mathrm{Ma}$ or ca. $30 \mathrm{Ma}$ ) (Ji et al., 2017; Wang et al., 2017b), the onset of deformation of the North Qaidam Thrust Belt and SQS occurred sometime during the Eocene-Oligocene period. This phase of contractional deformation has been broadly detected in many other parts of the northern Tibetan plateau, including the Eastern Kunlun Shan (Cheng et al., 2016a; Liu et al., 2017; Wang et al., 2017a), Altyn Tagh Shan (Cheng et al., 2015a; Cheng et al., 2016b; Yin et al., 2002), Qaidam basin 
(Cheng et al., 2019a; Yin et al., 2008b), western Qinling (Duvall et al., 2011), Lanzhou basin (Wang et al., 2017c), Pamir salient (Cao et al., 2013), and Fenghuo Shan (Staisch et al., 2014).

It is still ambiguous that whether the NQS has significantly experienced an early Cenozoic deformation (He et al., 2018; Pang et al., 2019a; Yu et al., 2019). Some studies suggest an early Cenozoic deformation in the NQS (He et al., 2017; He et al., 2018) and a recent study show some early Cenozoic AFT ages in the northernmost Qilian Shan (Pang et al., 2019b); however, we should note that some sedimentology and low-temperature thermochronology data fit multiple interpretations and the source area of those studied Cenozoic strata are still ambiguous. For instance, a 50-30 Ma onset of deformation in the NQS might be established based on bedrocks apatite fission track analysis carried out by Jolivet et al. (2001). However, we note that the analyzed NQS sample (Sample AT147) has a complex modelled inverse time-temperature (T-t) path with a large uncertainty, and recent apatite fission track data for bedrock samples in the NQS also show a stage of quasiistothermal quiescence from the late Cretaceous to the early Cenozoic (Pan et al., 2013). Miocene rapid cooling of the NQS is much clearer compared with the inferred $50-30 \mathrm{Ma}$ initial rapid cooling. We therefore propose that the early Cenozoic deformation might be mostly limited to the SQS, and further effort on the early Cenozoic deformation history in the NQS is still needed.

Rapid exhumation across the entire Qilian Shan in the Miocene has been documented by several lines of investigation, mainly including bedrock and detrital mineral low-temperature thermochronology studies, provenance analysis, as well as seismic profile interpretation (Bovet et al., 2009; Cheng et al., 2016a; Cheng et al., 2019b; Cheng et al., 2016c; He et al., 2017; He et al., 2018; Jolivet et al., 2001; Li et al., 2019; Qi et al., 2016b; Wang et al., 2016a; Wang et al., 2016b; Yin et al., 2008a; Yin et al., 2008b; Yu et al., 2019; Zheng et al., 2010; Zheng et al., 2017; Zhuang et al., 2011b). Some relate Miocene deformation in the northern 
Tibetan plateau to variation in the kinematic evolution of the ATF, while others associate it with the removal of lithospheric mantle beneath north-central Tibet (Molnar et al., 1993; Wang et al., 2016b; Zheng et al., 2017). Although the mechanism that drove widespread Miocene deformation in the northern Tibetan plateau is still debated, recent studies have argued for a northward propagation of deformation in the Qilian Shan, especially in the NQS (Yu et al., 2019; Zheng et al., 2017).

Given the remote and inaccessible CQS, reliable bedrock apatite fission track data for the CQS basement are scarce. However, based on an integrated sedimentology, stratigraphy and compositional data from Cenozoic strata in the Jiuquan basin and subranges in the NQS, Bovet et al. (2009) proposed that crustal shortening and surface uplift began in the SQS prior to the Miocene, while shortening propagated into the CQS, NQS and Jiuquan basin during the middle Miocene ( 13 Ma) and Pliocene-Pleistocene ( 5-3.5 Ma), respectively. A follow-up study by Zhuang et al. (2011b) also argued for a post-early Miocene initial exhumation of the CQS. Based again on sedimentology, magnetostratigraphy and low-temperature thermochronological evidence from the Cenozoic strata along the ATF, Yin et al. (2002) argue for a pre-33 Ma exhumation of the Nanshan thrust belt, which corresponds to the CQS. Despite uncertainties, the abovementioned evidence might indicate an Oligocene to middle Miocene exhumation of the CQS.

Within the northern Qilian Shan, based on the apatite fission track data obtained from the bedrocks in the hanging wall of the Changma Fault and a complication of previous work, Zheng et al. (2017) suggested that the uplift of the Tuolai Shan (subrange in the northern Qilian Shan) initiated around 17-14 Ma. Apatite fission-track data from an elevation transect in the eastern part of Tuolai Shan also show a rapid cooling event that began at ca. 17-15 Ma (Yu et al., 2019). Despite that Yu et al. (2019) interpret this rapid cooling as the initial phase of in the hanging wall of the Haiyuan fault, both studies (Yu et al., 2019; Zheng et al., 2017) 
revealed the middle Miocene initial exhumation of the Tuolai Shan. Further northwards, bedrock and detrital apatite fission track and (U-Th)/He thermochronology data from the northern Qilian Shan and the northern front of the northern Qilian Shan revealed that rapid exhumation of the northern Qilian Shan occurred ca. 10 Ma, representing the initial faulting along the northern Qilian fault (Zheng et al., 2010; Zheng et al., 2017). This late Miocene rapid exhumation is also evidenced by the detrital apatite fission track thermochronology studies in the Jiuquan basin (He et al., 2017). Based on the growth strata shown on the seismic profiles in the Jiuquan basin and the magnetostratigraphic constraints on the depositional age of the Cenozoic strata, previous studies have proposed that the onset of thrusting along the Hanxia-Dahuanggou Fault along the northern front of the range dated to ca. 9-8 Ma (Chen et al., 2006a; Fang et al., 2005). We thus propose that the faults in the hinterland of northern Qilian Shan initiated during the middle Miocene while those faults along the northern margin of the northern Qilian Shan initiated during the late Miocene. We note that strike-slip faulting prevailed along the faults (e.g. Haiyuan fault) in the Qilian Shan region since the middle to late Miocene. This whole phase of 15-10 Ma strike-slip faulting with the Qilian Shan could be attributed to the accelerated strike-slip movement along the ATF since the middle Miocene (Cheng et al, 2015a), and contributes to accommodating crustal deformation within the Qilian Shan (Cheng et al, 2015b; Zuza and Yin, 2016). It would build or reduce taper locally based on the geometry of the strike-slip fault (dominantly transpressional or transtensional).

Combining the total structural relief of the range with the rates of rock uplift and denudation, Palumbo et al. (2009) argued for an $3.7 \pm 0.9$ Ma onset of deformation of the Yumu Shan (YMS). Integrated magnetostratigraphic and the sedimentologic studies, Liu et al. (2011a) suggested that the initial deformation of the Yumu Shan was not later than 5.9 Ma. Based on the bedrock apatite fission track thermochronology analysis, Wang et al. (2018) 
proposed a 4 Ma initial uplift of the Yumu Shan. Moreover, combining magnetostratigraphy and sedimentology evidence, such as the presence of unconformities/conglomerates and growth strata, in two low topographic ramp anticlines, namely the Laojunmiao anticline (LJM) and the Wenshu Shan (WSS), western Jiuquan basin( Fig. 8), several studies infer a 4.5-3.6 Ma onset time of deformation in both regions (Chen et al., 2006b; Fang et al., 2005; Song et al., 2001; Zhao et al., 2001; Zheng et al., 2017). According to a $0.26 \pm 0.06 \mathrm{~mm} / \mathrm{yr}$ fault slip rate and ca. $1 \mathrm{~km}$ offset estimate, Liu (2017) argued that the Heishan Fault (HSF) initiated at ca. 3.8 Ma. A recent magnetostratigraphy and sedimentology study of borehole samples in the Jiuquan basin also revealed an abrupt change in sediment accumulation rate at $3 \mathrm{Ma}$, indicative of synchronous initial uplift of the Yumu Shan (Hu et al., 2019). We therefore conclude that the structures in the southern Jiuquan basin might have initiated during the Pliocene (Fig. 9).

Further to the north, combining the heights of the Heili Shan (HLS) and the vertical component of the slip rate, Zheng et al. (2013c) proposed that the Heili Shan began uplift at 2 $\mathrm{Ma}$ (between $4 \mathrm{Ma}$ and $1 \mathrm{Ma}$ ). Hu et al. (2019) also attributed the $\sim 1.8 \mathrm{Ma}$ abrupt increase in sediment accumulation rates in the Jiuquan basin to the synchronous exhumation of the Heili Shan to the north. On the other hand, a much younger age of 0.6-0.2 Ma for the initial uplift of the Heili Shan has also been proposed (Hetzel et al., 2004). All these evidences are indicative of a Pleistocene-Quaternary initial uplift of the Heili Shan, northern Jiuquan basin. The above discussed deformation timing along the faults in the Qilian Shan and Jiuquan basin, especially those faults in the NQS and Jiuquan basin, suggest that deformation progressively propagated northward, forming a series of NW-SE striking mountain ranges. However, we also note the possibility of an early Cenozoic deformation in the NQS and preMiocene deformation in the central or southern Qilian Shan (He et al., 2017; He et al., 2018), 
which could be interpreted as few cross-cutting and/or out-of sequence deformation in the Qilian Shan.

5.4.2 A new scenario for the Qilian Shan wedge evolution

If the hypothesis of a Oligocene to middle Miocene initiation of the deformation in the CQS is correct, the Qilian Shan would generally present a stepwise northward expansion, from early Cenozoic (Eocene to Oligocene) initial deformation in the Northern Qaidam Thrust Belt and SQS, to Oligocene to middle Miocene initial deformation in the CQS, middle to late Miocene initial deformation in the NQS, Pliocene initial faulting along the faults in the southern Jiuquan basin, and finally Pleistocene-Quaternary initial movement along the faults in the northern Jiuquan basin. In the following section, we propose a new qualitative interpretation of the behavior of the Qilian Shan wedge evolution in terms of long-term trends in overall wedge taper (Fig. 9).

During Eocene-Oligocene time, increasing rainfall in this region overpowered the contemporaneous contractional tectonics within the surrounding mountain belts. The resultant increase in sediment flux filled the basin, which limited the relative relief between basin and mountain ranges and led to a basin-scale transgression (Fig. 8)(Cheng et al,, 2016a). The erosion of material from the growing Qilian Shan orogenic wedge, accelerated by the strong precipitation, would have reduced the wedge taper. The Qilian Shan wedge was thus under a subcritical condition. We propose that the internal deformation (out of sequence thrusting or duplexing) within the SQS was insufficient to build the Qilian Shan wedge to a critical taper angle compared with the intense erosion, and this resulted in stalling of the Qilian Shan wedge (Fig. 9d and 9i). This inference is supported by the observation that the Eocene to Oligocene faulting along the thrusts were mostly restricted to the North Qaidam Thrust Belt and SQS, and did not extend outward to the central or northern Qilian Shan at this time (Figs. 8a, 9a, 9c)(Duvall et al., 2013; Yin et al., 2002; Yuan et al., 2013). 
As discussed in the section 5.2, the widespread aeolian accumulation throughout western China supports the inference of regional climate aridification, including the Qilian Shan from Oligocene to early Miocene time. Inasmuch as erosion is largely driven by precipitation (Lease et al., 2016), aridification in the Qilian Shan region since the late Oligocene to early Miocene led to a decrease in rainfall and a slowing of the erosion rate, contributing to rebuilding the critical taper via continuous internal deformation or by blocking the activity of the frontal thrusts via piling up sediment on top of them (Lallemand et al., 1994). We propose that the continuous internal tectonic deformation in the Qilian Shan, which brought basement material to the surface, gradually caught up with the erosional pace (Fig. 9e and 9j). The subcritical Qilian Shan wedge may have become supercritical, with the taper value ultimately exceeding critical taper. Forward thrust propagation (e.g., initiation of the CQS, F1) would have broaden the wedge to reduce the overall wedge taper (Fig. 9f and $9 \mathrm{k})$.

Since the middle Miocene, the sustained regional aridification would have resulted in a lower erosion rate of basement rocks in the Qilian Shan, maintaining the supercritical state of the wedge. This sustained supercritical state, led to continued outward growth of the Qilian Shan wedge, with its deformation front propagating progressively northwards to the fault systems in the NQS (F2 and F3, middle to late Miocene), followed by the southern Jiuquan basin (F4, Pliocene) and then to faults in the northern Jiuquan basin (F5, Pleistocene to Quaternary), progressively (Fig. 9g-9h and 9l-9m).

The inferred taper geometry is presented in Fig. 9c. Considering a 4-5 km average elevation in the SQS, the 15-20 km deep basement décollement beneath the SQS and the $>200 \mathrm{~km}$ distance between the SQS and the northern margin of the Jiuquan basin, we infer a gentle surface slope $\left(\alpha=1-2^{\circ}\right)$ and basal décollement $\left(\beta=5-8^{\circ}\right)$. Our inferred dip for the basal décollement is lower than the value $\left(\sim 15^{\circ}\right)$ estimated by Allen et al. (2017). This difference 
could be partly attributed to the fact that the Jiuquan basin that contains thick sedimentary rocks is taken into account in our wedge model, while Allen et al. (2017) concentrated on the Qilian Shan region. The dip of the basal décollement beneath the sedimentary rocks is smaller than beneath the basement rocks (DeCelles and Mitra, 1995), thus the average dip in our wedge model is smaller. We also note that the modern Qilian Shan is acting as a nascent plateau (Liu- Zeng et al., 2008), with subdued relief and internal drainage, and the surface slope in the NQS is steeper than that of in the SQS (Allen et al., 2017). However, the average elevation of the Qilian Shan decreases northward gradually, from over $4.5 \mathrm{~km}$ in the hinterland of the SQS to less than $3 \mathrm{~km}$ at the northern front of the NQS and to less than $2 \mathrm{~km}$ along the northern margin of the Jiuquan basin to the north.

The wide width of the active Qilian Shan and distribution of active faulting (or recently active faulting) throughout the Qilian Shan probably require a weak basal detachment (with low friction). The exploitation of the early Paleozoic suture zones by Cenozoic thrust faults suggests that these south-dipping suture zones are important for the Cenozoic Qilian Shan (Zuza et al., 2018a; Zuza et al., 2018b), probably acting as weak detachment horizons that enabled deformation to quickly propagate $\sim 2000 \mathrm{~km}$ north of the India-Asia collisional front. Previous studies have argued that the basement rocks become much weaker as contractional deformation progressed (DeCelles and Mitra, 1995). If the Qilian Shan contained a weak detachment zone during the early Cenozoic, then the basal detachment would become even weaker (lower friction) as deformation progressed. Thus, the progressive contractional deformation would also progressively decrease the $\theta_{\mathrm{c}}$ (the angel of taper when wedge reaches a critical state) of the Qilian Shan wedge. A counter argument to the above-described scenario is that the Qilian Shan wedge was subcritical, and the taper $\theta$ was larger than $\theta_{\mathrm{c}}$ during the early Cenozoic. As thick-skinned deformation progressed, the basal detachment would become weaker and the $\theta_{\mathrm{c}}$ of the Qilian Shan wedge taper would have progressively 
decreased. At some point during the Oligocene to early Miocene, the taper value ultimately exceeded critical taper $\theta_{\mathrm{c}}$ and the Qilian Shan wedge thereby became critical/supercritical. To decrease the taper $\theta$, the Qilian Shan wedge propagated progressively northward, resulting in the Oligocene to middle Miocene initial deformation in the CQS, the middle to late Miocene initial deformation in the NQS and the Pliocene to Quaternary initial deformation in the Jiuquan basin. This model requires a relatively high initial taper for the Qilian Shan wedge and a basal detachment with low friction. Without detailed crustal shortening restoration, it is difficult to estimate the initial taper of the wedge. In addition, other important parameters, such as pore fluid pressure, and rock strength within the Qilian Shan wedge, are not quantifiable. These uncertainties highlight the need for further effort to determine the kinematic evolution of the south and central Qilian Shan.

The structural evolution of the Qilian Shan compared with evidence of local climate change reveals that the Cenozoic growth of the northeastern margin of the Tibetan plateau obeys critical-taper wedge theory, with the tectonic evolution of Qilian Shan being integrally tied to the climate evolution in this region. It suggests that northward thrust propagation within the Qilian Shan might have promoted the northeastward migration of the tip of the ATF. As long as continuous shortening applies to the Qilian Shan, regional Miocene aridification would maintain a taper sufficient for northward propagation of the Qilian Shan orogenic wedge and the tip of the ATF.

Our inferred scenario shows an $~ 30$ to 50 Ma growth cycle (depending on the basal age of the Lulehe Fm.) for the Qilian Shan orogenic wedge, which is larger than the periodicity of the Sevier orogenic wedge (10-20 Ma) (DeCelles and Mitra, 1995), central Andean orogenic wedge (10-20 Ma) (Lease et al., 2016), European Alps (20-30 Ma) (Carrapa, 2009), and Pyrenees orogeny (20-30 Ma) (Jolivet et al., 2007). The Qilian Shan orogenic wedge is a thick-skinned structure and involves complex deformation of polyphase deformed rocks. 
Therefore, the kinematic evolution of the fault systems (e.g. deep structures) in the Qilian Shan orogenic wedge might be different from that the Andes or North American Cordillera orogenic belts. However, the upper parts of these tapered wedges might be similar. We infer that diverse internal (e.g. rock durability) and external (e.g. climate condition) factors in those orogenic wedges lead to the different periodicity of the orogenic wedge.

If correct, our work highlights that climate shifts in central Asia could have strongly affected the growth of the mountain ranges in the northern Tibetan plateau. The Cenozoic evolution of the northern Tibetan plateau cannot be evaluated without understanding of how the climate has influenced the kinematic history of this region. Further effort that provides independent constraints on the Cenozoic climate history of the Qilian Shan and surrounding regions is necessary to fully evaluate the influence of climate on outward growth of the plateau.

\section{Conclusions}

In this study, we integrate new detrital zircon geochronological data with seismic profiles and drill core data from NE Qaidam and Suganhu basins to investigate mountain building of the Qilian Shan as well as the source to sink relationship between Qilian Shan and adjacent basins. Our analyses lead us to conclude the following:

1. The SQS served as a significant source for the sediments in both NE Qaidam basin and the Suganhu basin during the deposition of Lulehe to Shangganchaigou Fm. The link between the NE Qaidam basin and the Suganhu basin, as well as the SQS, was cut off in the Miocene.

2. Increased precipitation may have driven basin-scale transgression processes in the Qaidam basin during the Paleogene. Since then, the Qaidam basin was gradually isolated in response to regional aridification and intensified deformation within the surrounding mountain belts. 
3. Cenozoic growth of the Qilian Shan obeys critical-taper wedge theory. During the Paleogene, wet climate conditions enabled erosion to overpower the tectonic thickening in the SQS orogenic wedge and caused the wedge to stall. Since the Miocene, continuous deformation in the SQS under more arid climate conditions and lower erosion rates enabled deformation to build wedge taper to a supercritical state that caused the wedge to propagate northward.

4. Our observations that the Qilian Shan growth history obeys critical taper theory highlights that climate may have played a significant role in mountain building in the northern Tibetan plateau and should be evaluated in the context of the outward growth of the Tibetan plateau.

\section{Acknowledgement}

This manuscript benefited from conversations with Eric Kirby, An Yin, and Devon Orme. This research was funded by grants from the National Science Foundation (EAR-1348005 and OISE-1545859) to Garzione, the Key Program of the National Natural Science Foundation of China (Grant No. 41930213) to Guo and State Key Laboratory of Loess and Quaternary Geology, Institute of Earth Environment, CAS, open project fund (No. SKLLQG1701) to Cheng, National Science Foundation of China (No. 41672163) and the Youth Innovation Promotion Association, CAS to Li. We would like to thank Editor Douwe J.J. van Hinsbergen, Andrew Zuza and another anonymous reviewer for insightful suggestions that significantly improved the manuscript.

\section{Figure Caption}

Figure 1. (a) Topographic map of the Tibetan plateau. NQS, CQS, and SQS refer to northern Qilian Shan, central Qilian Shan and southern Qilian Shan, respectively. (b) Geological map of the NE Qaidam basin, Suganhu basin and southern Qilian Shan. 
Figure 2. Generalized stratigraphic column of the Cenozoic strata within the Qaidam basin and Suganhu basin. Traditional age model for the strata is compiled from Ji et al. (2017) and new age model for the strata is from Wang et al. (2017b). GPTS, geomagnetic polarity time scale.

Figure 3. (a) Sketched geological map of the Qaidam basin, Suganhu basin and surrounding orogenic belts, showing the distribution of zircon $\mathrm{U}-\mathrm{Pb}$ ages for granitoids. WQB, SQB, NWQB and EQB are abbreviations of Western Qaidam basin, Southern Qaidam basin, Northwestern Qaidam and eastern Qaidam basin, respectively, representing the location of previous detrital zircon geochronology study (Bush et al., 2016; Cheng et al., 2016a; Cheng et al., 2016b; Wang et al., 2017b). NEQB and SGHB are abbreviations of northeastern Qaidam basin and Suganhu basin, showing the location of detrital zircon geochronology in this study. (b) and (c) show the relative probability plot of granitoid pluton ages (compilation of bedrock pluton ages) in the northern Qaidam terrane and southern Qilian Shan, respectively. The $\mathrm{U}-\mathrm{Pb}$ age dataset is from Cheng et al. (2017). (c)-(i) Zircon U-Pb age cumulative probability distribution for each sample. The ages, in Ma, are indicated on the horizontal axis. Green arrows show that the distribution of the ages becomes more diverse, from the Lulehe Fm. sample to the Shangganchaigou Fm. sample. Red wavy lines show that the Archean-Paleoproterozoic zircons become scarce since the deposition of Xiayoushashan Fm. (r) Cumulative probability density plots for Cenozoic samples from NE Qaidam basin and Suganhu basin. (s) Multidimensional scaling map uses the Kolmogorov-Smirnov (KS) statistic for detrital zircon U-Pb datasets (Vermeesch, 2013), showing the distinct signature of the northern Qaidam terrane and southern Qilian Shan source regions. Axes are in dimensionless "K-S units" $(0<\mathrm{KS}<1)$, showing distance between samples. Solid lines and 
dashed lines connect samples with their "closest" and "second closest" neighbors, respectively. Note that zircon age distributions from samples $\mathrm{P}-\mathrm{E}_{1+2}, \mathrm{SS} 3-\mathrm{E}_{3}{ }^{1}, \mathrm{SS} 3-\mathrm{E}_{3}{ }^{2}, \mathrm{SS} 3-$ $\mathrm{N}_{1}, \mathrm{SS} 3-\mathrm{N}_{2}{ }^{1}-\mathrm{b}, \mathrm{SS} 3-\mathrm{N}_{2}{ }^{1}-\mathrm{t}, \mathrm{SS} 3-\mathrm{N}_{2}{ }^{2}, \mathrm{SS} 3-\mathrm{N}_{2}{ }^{3}$ and $\mathrm{SS} 3-\mathrm{Q}_{1}$ are statistically similar with those of granitoid plutons from the northern Qaidam terrane, whereas zircon age distributions from samples $\mathrm{S} 3-\mathrm{E}_{1+2}, \mathrm{~S} 3-\mathrm{E}_{3}{ }^{1}, \mathrm{~S} 3-\mathrm{E}_{3}{ }^{2}, \mathrm{~S} 3-\mathrm{N}_{1}, \mathrm{~S} 3-\mathrm{N}_{2}{ }^{1}$ and $\mathrm{S} 3-\mathrm{Q}_{1}$, are statistically similar with those of granitoid plutons from the southern Qilian Shan.

Figure 4. Two seismic sections (AA' and BB') through the Suganhu basin, showing the fault structure and strata distribution. (a) and (c) are oriented seismic sections, and interpretations are shown on (b) and (d). Note that Faults Fs1, Fs2 and Fs3 initiated since the deposition of Lulehe Fm.

Figure 5. (a) Well-correlation diagram of the Lulehe Fm. and Xiaganchaigou Fm. strata along the southern flank of the northern Qaidam terrane based on well-log and drill core data. The locations of the selected drill cores are shown in Fig. 5b-5d.(b)-(d) show the distribution of facies during the deposition of Lulehe, Lower Xiaganchaigou, and Upper Xiaganchaigou formations in the NE Qaidam, modified from Zou et al. (2015). The locations of Fig. 5b-5d are shown in Fig. 1a. Note the retrogradation of the shoreline from the Lulehe Fm. to Upper Xiaganchaigou Fm. (e) Time slice $(0.660$ second) showing the geometry of Sainan fault and Tuonan-Pingdong fault. (f) and (g) are uninterpreted seismic sections (CC' and DD') in the NE Qaidam basin, showing the upper structural and strata distribution. Interpretations are shown on (b) and (d). Note that the Sainan fault and Tuonan-Pingdong fault initiated since the deposition of Lulehe Fm. $\mathrm{E}_{1+2}$ l: Lulehe Fm., $\mathrm{E}_{3}{ }^{1} \mathrm{xg}$ : Lower Xiaganchaigou Fm., $\mathrm{E}_{3}{ }^{2} \mathrm{xg}$ : Upper Xiaganchaigou Fm., $\mathrm{N}_{1}$ sg: Shangganchaigou Fm., $\mathrm{N}_{2}{ }^{1}$ xy: Xiayoushashan Fm., $\mathrm{N}_{2}{ }^{2}$ sy: Shangyoushashan Fm., $\mathrm{N}_{2}{ }^{3}$ s: Shizigou Fm., Q1 q: Qigequan Fm. 
Figure 6. (a) Well-correlation diagram of the Lulehe Fm. and Xiaganchaigou Fm. strata along the northern flank of the Eastern Kunlun Shan based on well-log and drill core data. The locations of the selected drill cores are shown in Fig. 6b-6c. (b) and (c) show the distribution of facies during the deposition of Lulehe and Lower Xiaganchaigou formations in the NE Qaidam, modified from Zhang et al. (2013). Location of Fig. 6b and $6 \mathrm{c}$ is shown in Fig. 1a. Note the landward migration of the shoreline from the Lulehe Fm. to Lower Xiaganchaigou Fm. (d) Time slice (0.848 s) showing the geometry of Kunbei fault. (e) and (g) are uninterpreted seismic sections (EE') in the SW Qaidam basin, showing the upper structural and strata distribution. Interpretation is shown on (f) and (h). Note the successive westward onlap of the Lulehe and Lower Xiaganchaigou formations.

Figure 7. Zircon $\mathrm{U}-\mathrm{Pb}$ age cumulative probability distribution for Cenozoic sandstone samples from different parts of the Qaidam basin and relative probability plot of granitoid pluton ages in the surrounding mountain belts. Zircon $\mathrm{U}-\mathrm{Pb}$ ages from Cenozoic sandstone are mainly compiled from this study and previous work (Bush et al., 2016; Cheng et al., 2016a; Cheng et al., 2016b; Wang et al., 2017b; Zhou et al., 2018). The locations of those studies are shown in Fig. 3a. Previous published zircon $\mathrm{U}-\mathrm{Pb}$ age cumulative probability distribution of modern river samples (Wang et al, 2016b), are used to characterize the age of granitoid plutons in the northern and central Qilian Shan. The zircon U-Pb ages cumulative probability distributions used to characterize the age of granitoid plutons in the surrounding mountains are compiled from previous work (Cheng et al., 2016b; Cheng et al., 2017; Dai et al., 2012). See caption of Fig. 3 for details. The curves show the Cenozoic source to sink relation between the Qaidam basin and surrounding mountain belts. Green arrows show that the distribution of the ages becomes more diverse, from the Lulehe Fm. sample to the 
Shangganchaigou Fm., in response to the basin-scale expansion of the Qaidam basin drainage area.

Figure 8. (a) Topographic map of the northern Tibetan plateau, showing ranges in the Qilian Shan. NQDF: Northern Qaidam fault system, DNF: Danghe-Nanshan fault, NQF: northern Qilian fault, LJM: Laojunmiao anticline, HLS: Heli Shan fault, HSF: Heishan fault. WSS: Wenshu Shan, YMS: Yumu Shan. The 15-10 Ma initiation of the strike-slip faulting along the Haiyuan fault is from ( $\mathrm{Li}$ et al., 2019). The suggested onset time of deformation along DNF faults is based on the previous studies (Duvall et al., 2013; Yin et al., 2002). Cenozoic faults are mainly based on previous studies (Zhang et al., 2017; Zheng et al., 2017). The onset time of deformation along F1, F2, F3, F4, and F5 are given in Figure 9. Note that profile FF' only crosses the western part of the Qilian Shan. (b)-(g) show the oxygen isotope records from the lacustrine strata (Lower Xiaganchaigou to Shangganchaigou formations) within the Qaidam basin (Li et al., 2016; Li et al., 2017; Mao et al., 2014; Rieser et al., 2009). Red dashed arrows show decrease in oxygen isotopic compositions during deposition of Lower Xiaganchaigou Fm. to Shangganchaigou Fm. Blue dashed line show the average $\delta^{18} \mathrm{O}$ value of each stage. We thus infer relatively humid climate in the Qaidam basin and surrounding region during the deposition Lower Xiaganchaigou to Shangganchaigou formations (Fig. 8i). (h)-(j) Scenarios for the evolution of the Qaidam basin during the Cenozoic. Note the expanding lacustrine environment of the Qaidam basin during deposition of Lulehe to Shangganchaigou formations (from Fig. 8h to Fig. 8i) and the isolation of the Qaidam basin during the deposition of Xiaganchaigou Fm. to the present (from Fig. 8i to Fig. 8j).

Figure 9. Scenarios for the progressive northward growth of the Qilian Shan in terms of critical wedge theory. (a) Oblique view of the Qilian Shan, showing the initial deformation of 
ranges in the Qilian Shan. DNF: Danghe-Nanshan fault, F1 refers to the fault system in the CQS, F2 refers to the fault in the NQS (e.g. Changma Fault in the western part of the NQS, Haiyuan Fault in the eastern part of the NQS), F3 refers to the northern Qilian fault and Hanxia fault. F4 refers to the fault system beneath the Laojunmiao anticline, Wenshu Shan and Yumu Shan. F5 refers to the fault in the northern Jiuquan basin (Heili Shan fault). These faults are shown in Fig. 8. The suggested onset time of deformation along these faults is based on the previous low-temperature thermochronology and provenance studies (Bovet et al., 2009; Chen et al., 2006a; Fang et al., 2005; Hetzel et al., 2004; Hu et al., 2019; Liu, 2017; Palumbo et al., 2009; Song et al., 2001; Wang et al., 2018; Yuan et al., 2013; Zhao et al., 2001; Zheng et al., 2010; Zheng et al., 2017; Zheng et al., 2013c; Zhuang et al., 2011b). (b) Schematic diagram illustrating the geometry of a Coulomb wedge under the influence of a push from behind (black arrows). Wedge taper $(\theta)$ equals the sum of surface slope $(\alpha)$ plus the angel of basal décollement $(\beta) . \theta_{c}$ refers to the angel of taper when wedge reaches a critical state. If $\theta>\theta_{c}$, the wedge will tend to lengthen itself by frontal imbrication, thus reducing $\theta$ to a critical value. If $\theta>\theta_{c}$, the rear of the wedge should shorten and thicken to increase $\theta$ (Dahlen and Suppe, 1988; Davis et al., 1983; DeCelles and Mitra, 1995). (c) Schematic cross-section across the western part of the Qilian Shan, showing our Qilian Shan wedge taper model. Given the 4-5 km elevation in the southern and central Qilian Shan and the over $200 \mathrm{~km}$ distance from the southern Qilian Shan to the northern Jiuquan basin, we infer a gentle surface slope $\left(\alpha=1-2^{\circ}\right)$ and basal décollement $\left(\beta=5-8^{\circ}\right)$. The inferred dip of the basal décollement is lower than the value $\left(\sim 15^{\circ}\right)$ estimated by Allen et al. (2017). This difference can be partly attributed to the fact that we take the Jiuquan basin that contains thick sedimentary rocks into account in our wedge model. The Qilian Shan is acting as a nascent plateau, with subdued relief and internal drainage (Allen et al., 2017; Liu - Zeng et al., 2008), However, the average elevation of the Qilian Shan decreases northwards gradually, 
from over $4.5 \mathrm{~km}$ at the hinterland to less than $3 \mathrm{~km}$ at its northern front. The depth of basal detachment thrust is ca. $15-20 \mathrm{~km}$, and the dip angle of all the faults near the surface is cat ca. 20-40 degree (Allen et al., 2017; Zheng et al., 2010; Zuza et al., 2016). (d) to (h) show the behavior of the wedge in terms of the critical taper theory, while (i) to (m) display the corresponding northward growth of the Qilian Shan from the deposition of Lulehe Fm. to the present.

Table 1 Summary of the major characteristics and corresponding $\mathrm{U}-\mathrm{Pb}$ age data for each sample.

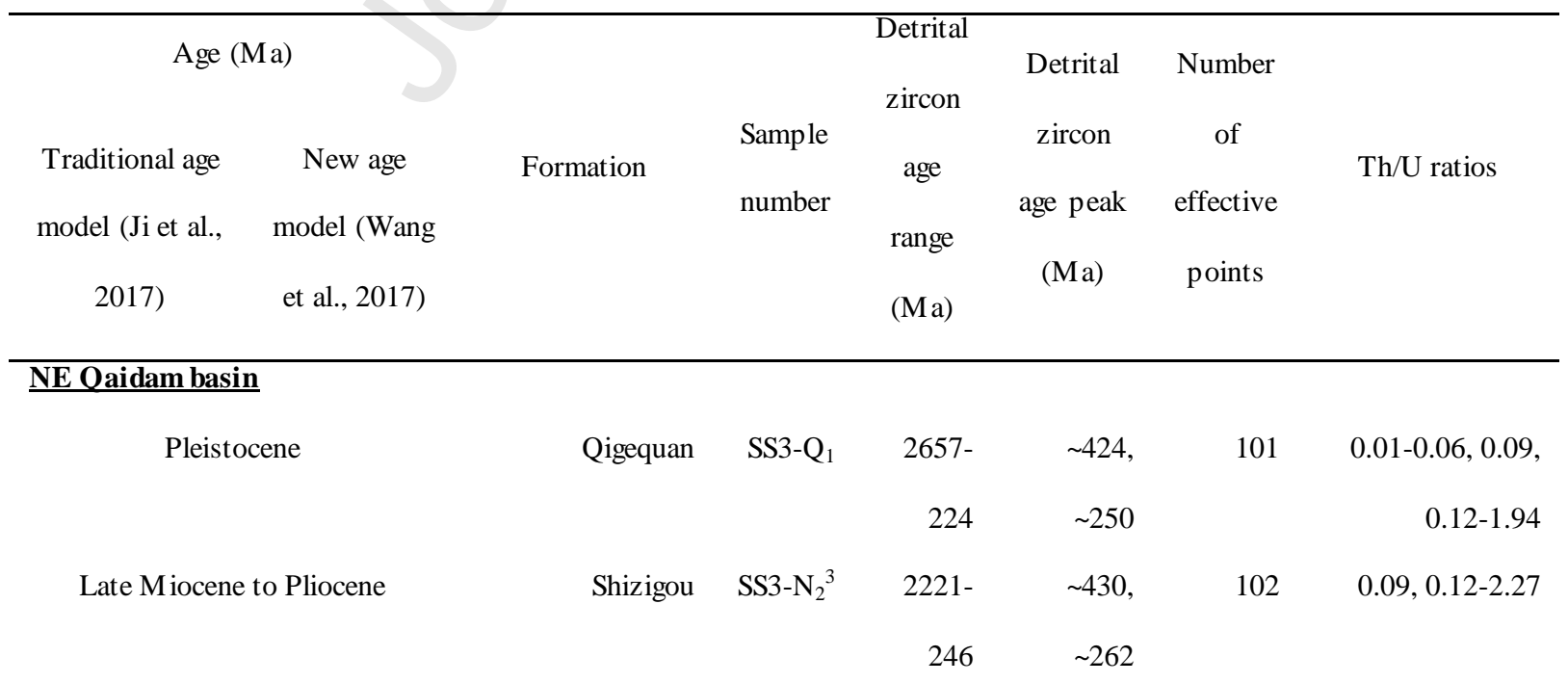




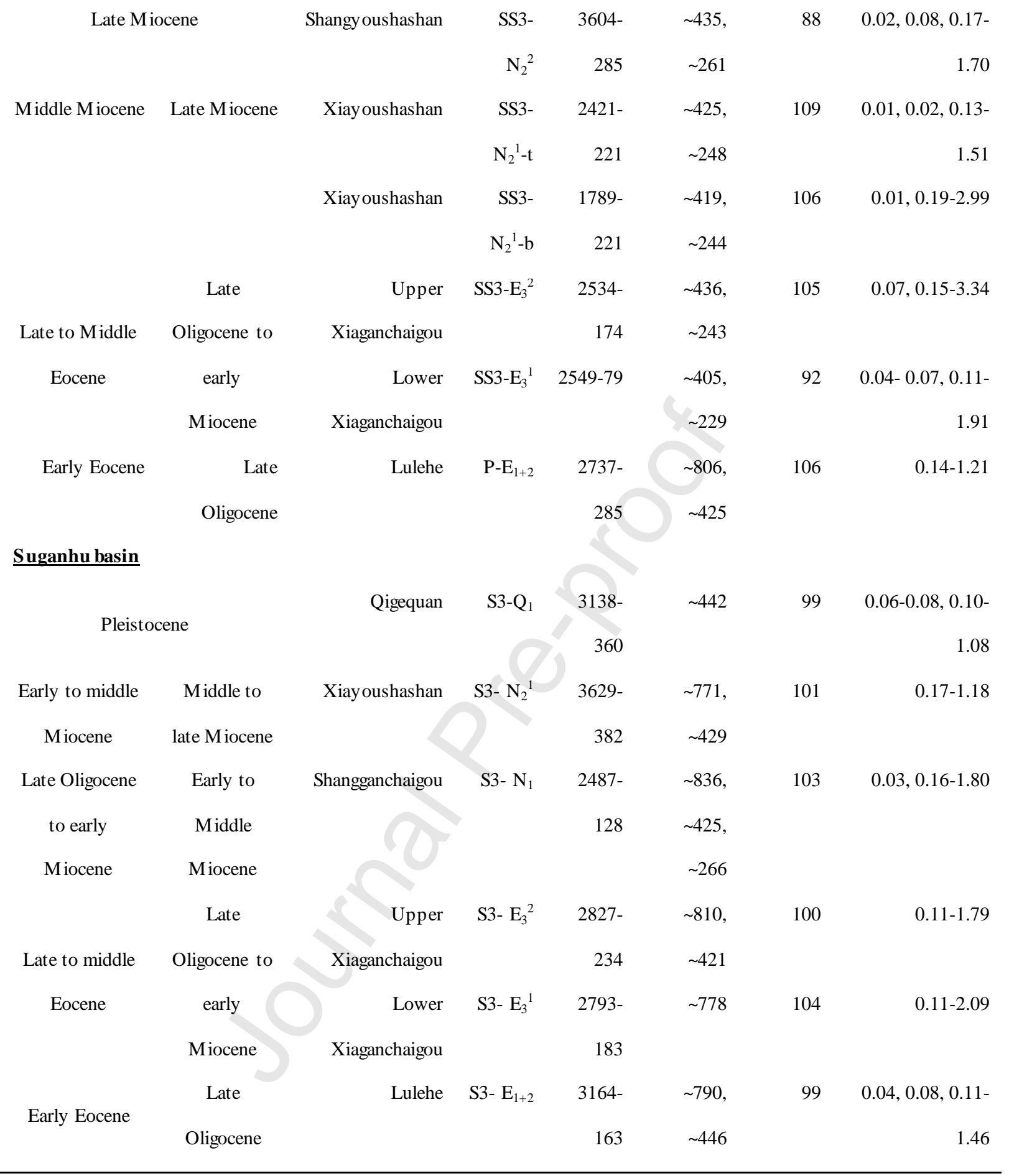

\section{References}

Allen, M.B., Walters, R.J., Song, S., Saville, C., De Paola, N., Ford, J., Hu, Z. and Sun, W., 2017. Partitioning of oblique convergence coupled to the fault locking behavior of fold - and - thrust belts: Evidence from the Qilian Shan, northeastern Tibetan Plateau. 
Tectonics, 36(9): 1679-1698.

Bosboom, R.E., Abels, H.A., Hoorn, C., van den Berg, B.C., Guo, Z. and Dupont-Nivet, G., 2014. Aridification in Continental Asia after the Middle Eocene Climatic Optimum (Meco). Earth and Planetary Science Letters, 389: 34-42.

Bovet, P.M., Ritts, B.D., Gehrels, G., Abbink, A.O., Darby, B. and Hourigan, J., 2009. Evidence of Miocene crustal shortening in the north Qilian Shan from Cenozoic stratigraphy of the western Hexi Corridor, Gansu Province, China. American Journal of Science, 309(4): 290-329.

Burchfiel, B.C., Quidong, D., Molnar, P., Royden, L., Yipeng, W., Peizhen, Z. and Weiqi, Z., 1989. Intracrustal detachment within zones of continental deformation. Geology, 17(8): 748-752.

Bush, M.A., Saylor, J.E., Horton, B.K. and Nie, J., 2016. Growth of the Qaidam Basin during Cenozoic exhumation in the northern Tibetan Plateau: Inferences from depositional patterns and multiproxy detrital provenance signatures. Lithosphere, 8(1): 58-82.

Cao, K., Wang, G.-C., van der Beek, P., Bernet, M. and Zhang, K.-X., 2013. Cenozoic thermo-tectonic evolution of the northeastern Pamir revealed by zircon and apatite fission-track thermochronology. Tectonophysics, 589: 17-32.

Carrapa, B., 2009. Tracing exhumation and orogenic wedge dynamics in the European Alps with detrital thermochronology. Geology, 37(12): 1127-1130.

Champagnac, J.D., Molnar, P., Sue, C. and Herman, F., 2012. Tectonics, climate, and mountain topography. Journal of Geophysical Research: Solid Earth, 117(B2).

Chang, H., Li, L., Qiang, X., Garzione, C.N., Pullen, A. and An, Z., 2015. Magnetostratigraphy of Cenozoic deposits in the western Qaidam Basin and its implication for the surface uplift of the northeastern margin of the Tibetan Plateau. Earth and Planetary Science Letters, 430: 271-283. 
Chen, H., Yang, S., Xiao, A., Pan, Z., Cheng, X., Chen, J., Fan, m. and Tian, D., 2006a. Deformation characteristics and time of Cenozoic thrust belt in southern margin of Jiuquan basin. IOil \& Gas Geology, 27(4): 488-494.

Chen, J., Wyrwoll, K., Lu, Y., Krapez, B., Wan, J. and Liu, J., 2006b. Magnetochronology of the Yumen conglomerates and multi-pulsed folding and thrusting in the northern Qilianshan. Quaternary Sciences, 26(1): 20-31.

Chen, Y., Gilder, S., Halim, N., Cogné, J.P. and Courtillot, V., 2002. New paleomagnetic constraints on central Asian kinematics: Displacement along the Altyn Tagh fault and rotation of the Qaidam Basin. Tectonics, 21(5): 1042.

Cheng, F., Fu, S., Jolivet, M., Zhang, C. and Guo, Z., 2016a. Source to sink relation between the Eastern Kunlun Range and the Qaidam Basin, northern Tibetan Plateau, during the Cenozoic. Geological Society of America Bulletin, 128(1-2): 258-283.

Cheng, F., Garzione, C., Jolivet, M., Guo, Z., Zhang, D. and Zhang, C., 2018. A New Sediment Accumulation Model of Cenozoic Depositional Ages From the Qaidam Basin, Tibetan Plateau. Journal of Geophysical Research: Earth Surface, 123(11): 3101-3121.

Cheng, F., Garzione, C., Jolivet, M., Guo, Z., Zhang, D., Zhang, C. and Zhang, Q., 2019a. Initial Deformation of the Northern Tibetan Plateau: Insights From Deposition of the Lulehe Formation in the Qaidam Basin. Tectonics, 38: 741-766.

Cheng, F., Garzione, C., Jolivet, M., Wang, W., Dong, J., Richter, F. and Guo, Z., 2019b. Provenance analysis of the Yumen Basin and northern Qilian Shan: Implications for the pre-collisional paleogeography in the NE Tibetan plateau and eastern termination of Altyn Tagh fault. Gondwana Research, 65: 156-171.

Cheng, F., Guo, Z., Jenkins, H.S., Fu, S. and Cheng, X., 2015a. Initial rupture and displacement on the Altyn Tagh fault, northern Tibetan Plateau: Constraints based on 
residual Mesozo ic to Cenozoic strata in the western Qaidam Basin. Geosphere, 11(3): 921-942.

Cheng, F., Jolivet, M., Dupont-Nivet, G., Wang, L., Yu, X. and Guo, Z., 2015b. Lateral extrusion along the Altyn Tagh Fault, Qilian Shan (NE Tibet): insight from a 3D crustal budget. Terra Nova, 27(6): 416-425.

Cheng, F., Jolivet, M., Fu, S., Zhang, C., Zhang, Q. and Guo, Z., 2016b. Large-scale displacement along the Altyn Tagh Fault (North Tibet) since its Eocene initiation: Insight from detrital zircon $\mathrm{U}-\mathrm{Pb}$ geochronology and subsurface data. Tectonophysics, 677-678: 261-279.

Cheng, F., Jolivet, M., Hallot, E., Zhang, D., Zhang, C. and Guo, Z., 2017. Tectonomagmatic rejuvenation of the Qaidam craton, northern Tibet. Gondwana Research, 49: 248-263.

Cheng, X., Lin, X., Wu, L., Chen, H., Xiao, A., Gong, J., Zhang, F. and Yang, S., 2016c. The exhumation history of north Qaidam thrust belt constrained by apatite fission track thermochronology: implication for the evolution of the Tibetan Plateau. Acta Geologica Sinica (English Edition), 90(3): 870-883.

Corfield, R.I. and Searle, M.P., 2000. Crustal shortening estimates across the north Indian Continental Margin, Ladakh, NW India. In: Khan, M.A., Treloar, P.J., Searle, M.P., Jan, M.Q. (Eds.), Tectonics of the Nanga Parbat Syntaxis and Western Himalaya. Geological So- ciety of London Special Publication 170: 395-410.

Corfu, F., Hanchar, J.M., Hoskin, P.W. and Kinny, P., 2003. Atlas of zircon textures. Reviews in mineralogy and geochemistry, 53(1): 469-500.

Cowgill, E., Yin, A., Harrison, T.M. and Xiao-Feng, W., 2003. Reconstruction of the Altyn Tagh fault based on U-Pb geochronology: Role of back thrusts, mantle sutures, and heterogeneous crustal strength in forming the Tibetan Plateau. Journal of Geophysical 
Research, 108(B7): 2346.

Craddock, W., Kirby, E. and Zhang, H., 2011. Late Miocene-Pliocene range growth in the interior of the northeastern Tibetan Plateau. Lithosphere, 3(6): 420-438.

Craddock, W.H., Kirby, E., Harkins, N.W., Zhang, H., Shi, X. and Liu, J., 2010. Rapid fluvial incision along the Yellow River during headward basin integration. Nature Geosci, 3(3): 209-213.

Craddock, W.H., Kirby, E., Miller, E.L., Zhang, H., Clark, M.K., Champagnac, J.-D. and Yuan, D., 2014. Rates and style of Cenozoic deformation around the Gonghe Basin, northeastern Tibetan Plateau. Geosphere.

Dahlen, F., 1990. Critical taper model of fold-and-thrust belts and accretionary wedges. Annual Review of Earth and Planetary Sciences, 18(1): 55-99.

Dahlen, F. and Suppe, J., 1988. Mechanics, growth, and erosion of mountain belts. Processes in continental lithospheric deformation: Geological Society of America Special Paper, 218: $161-178$.

Dai, J.G., Zhao, X.X., Wang, C.S., Zhu, L.D., Li, Y.L. and Finn, D., 2012. The vast protoTibetan Plateau: New constraints from Paleogene Hoh Xil Basin. Gondwana Research, 22(2): 434-446.

Davis, D., Suppe, J. and Dahlen, F., 1983. Mechanics of fold - and - thrust belts and accretionary wedges. Journal of Geophysical Research: Solid Earth, 88(B2): 11531172.

DeCelles, P.G. and Mitra, G., 1995. History of the Sevier orogenic wedge in terms of critical taper models, northeast Utah and southwest Wyoming. Geological Society of America Bulletin, 107(4): 454-462.

DeCelles, P.G., Robinson, D.M., Quade, J., Ojha, T.P., Garzione, C.N., Copeland, P. and Upreti, B.N., 2001. Stratigraphy, structure, and tectonic evolution of the Himalayan 
fold-thrust belt in western Nepal. Tectonics, 20(4): 487-509.

Dettman, D.L., Fang, X., Garzione, C.N. and Li, J., 2003. Uplift-driven climate change at 12 Ma: a long $\delta 180$ record from the NE margin of the Tibetan plateau. Earth and Planetary Science Letters, 214(1-2): 267-277.

Dupont-Nivet, G., Krijgsman, W., Langereis, C.G., Abels, H.A., Dai, S. and Fang, X., 2007. Tibetan plateau aridification linked to global cooling at the Eocene-Oligocene transition. Nature, 445(7128): 635-638.

Dupont - Nivet, G., Lippert, P.C., Van Hinsbergen, D.J.J., Meijers, M.J.M. and Kapp, P., 2010. Palaeolatitude and age of the Indo-Asia collision: palaeomagnetic constraints. Geophysical Journal International, 182(3): 1189-1198.

Duvall, A.R., Clark, M.K., Kirby, E., Farley, K.A., Craddock, W.H., Li, C. and Yuan, D.-Y., 2013. Low-temperature thermochronometry along the Kunlun and Haiyuan Faults, NE Tibetan Plateau: Evidence for kinematic change during late-stage orogenesis. Tectonics, 32(5): 1190-1211.

Duvall, A.R., Clark, M.K., van der Pluijm, B.A. and Li, C., 2011. Direct dating of Eocene reverse faulting in northeastern Tibet using Ar-dating of fault clays and lowtemperature thermochronometry. Earth and Planetary Science Letters, 304(3-4): 520526.

Elliott, D., 1976. The motion of thrust sheets. Journal of Geophysical research, 81(5): 949963.

Fang, X., Zhang, W., Meng, Q., Gao, J., Wang, X., King, J., Song, C., Dai, S. and Miao, Y., 2007. High-resolution magnetostratigraphy of the Neogene Huaitoutala section in the eastern Qaidam Basin on the NE Tibetan Plateau, Qinghai Province, China and its implication on tectonic uplift of the NE Tibetan Plateau. Earth and Planetary Science Letters, 258(1-2): 293-306. 
Fang, X., Zhao, Z., Li, J., Yan, M., Pan, B., Song, C. and Dai, S., 2005. Magnetostratigraphy of the late Cenozoic Laojunmiao anticline in the northern Qilian Mountains and its implications for the northern Tibetan Plateau uplift. Science in China Series D-Earth Sciences, 48(7): 1040 .

Gehrels, G.E., Yin, A. and Wang, X.F., 2003. Magmatic history of the northeastern Tibetan Plateau. Journal of Geophysical Research, 108(B9): 2423.

George, A.D., Marshallsea, S.J., Wyrwoll, K.-H., Jie, C. and Yanchou, L., 2001. Miocene cooling in the northern Qilian Shan, northeastern margin of the Tibetan Plateau, revealed by apatite fission-track and vitrinite-reflectance analysis. Geology, 29(10): 939-942.

Glass, S.W. and Wilkinson, B.H., 1980. The peterson limestone - early cretaceous lacustrine carbonate deposition in western wyoming and southeastern idaho. Sedimentary Geology, 27(2): 143-160.

Grujic, D., Coutand, I., Bookhagen, B., Bonnet, S., Blythe, A. and Duncan, C., 2006. Climatic forcing of erosion, landscape, and tectonics in the Bhutan Himalayas. Geology, 34(10): 801-804.

Guo, Z., Ruddiman, W.F., Hao, Q., Wu, H., Qiao, Y., Zhu, R.X., Peng, S., Wei, J., Yuan, B. and Liu, T., 2002. Onset of Asian desertification by $22 \mathrm{Myr}$ ago inferred from loess deposits in China. Nature, 416(6877): 159-163.

He, P., Song, C., Wang, Y., Chen, L., Chang, P., Wang, Q. and Ren, B., 2017. Cenozoic exhumation in the Qilian Shan, northeastern Tibetan Plateau: Evidence from detrital fission track thermochronology in the Jiuquan Basin. Journal of Geophysical Research: Solid Earth, 122(8): 6910-6927.

He, P., Song, C., Wang, Y., Meng, Q., Chen, L., Yao, L., Huang, R., Feng, W. and Chen, S., 2018. Cenozoic deformation history of the Qilian Shan (northeastern Tibetan Plateau) 
constrained by detrital apatite fission-track thermochronology in the northeastern Qaidam Basin. Tectonophysics, 749: 1-11.

Heermance, R.V., Pearson, J., Moe, A., Langtao, L., Jianhong, X., Jie, C., Richter, F., Garzione, C.N., Junsheng, N. and Bogue, S., 2018. Erg deposition and development of the ancestral Taklimakan Desert (western China) between 12.2 and 7.0 Ma. Geology, 46(10): 919-922.

Herman, F., Seward, D., Valla, P.G., Carter, A., Kohn, B., Willett, S.D. and Ehlers, T.A., 2013. Worldwide acceleration of mountain erosion under a cooling climate. Nature, 504(7480): 423.

Hetzel, R., Tao, M., Niedermann, S., Strecker, M.R., Ivy - Ochs, S., Kubik, P.W. and Gao, B., 2004. Implications of the fault scaling law for the growth of topography: Mountain ranges in the broken foreland of north - east Tibet. Terra Nova, 16(3): 157-162.

Horton, B.K., 1999. Erosional control on the geometry and kinematics of thrust belt development in the central Andes. Tectonics, 18(6): 1292-1304.

Hoskin, P. and Black, L., 2000. Metamorphic zircon formation by solid - state recrystallization of protolith igneous zircon. Journal of metamorphic Geology, 18(4): 423-439.

Hu, X., Chen, D., Pan, B., Chen, J., Zhang, J., Chang, J., Gong, C. and Zhao, Q., 2019. Sedimentary evolution of the foreland basin in the NE Tibetan Plateau and the growth of the Qilian Shan since 7 Ma. GSA Bulletin.

Hu, X., Garzanti, E., Moore, T. and Raffi, I., 2015. Direct stratigraphic dating of India-Asia

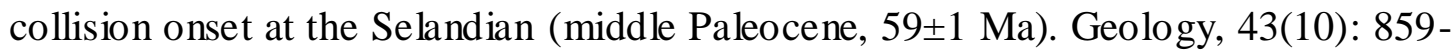
862.

Hubbard, J. and Shaw, J.H., 2009. Uplift of the Longmen Shan and Tibetan plateau, and the 2008 Wenchuan ( $M=7.9)$ earthquake. Nature, 458(7235): 194-197. 
Hubbard, J., Shaw, J.H. and Klinger, Y., 2010. Structural Setting of the 2008 Mw 7.9 Wenchuan, China, Earthquake. Bulletin of the Seismological Society of America, 100(5B): 2713-2735.

Ji, J., Zhang, K., Clift, P.D., Zhuang, G., Song, B., Ke, X. and Xu, Y., 2017. High-resolution magnetostratigraphic study of the Paleogene-Neogene strata in the Northern Qaidam Basin: Implications for the growth of the Northeastern Tibetan Plateau. Gondwana Research, 46: 141-155.

Jolivet, M., Brunel, M., Seward, D., Xu, Z., Yang, J., Roger, F., Tapponnier, P., Malavieille, J., Arnaud, N. and Wu, C., 2001. Mesozoic and Cenozoic tectonics of the northern edge of the Tibetan plateau: fission-track constraints. Tectonophysics, 343(1-2): 111134.

Jolivet, M., Dominguez, S., Charreau, J., Chen, Y., Li, Y. and Wang, Q., 2010. Mesozoic and Cenozoic tectonic history of the central Chinese Tian Shan: Reactivated tectonic structures and active deformation. Tectonics, 29(6).

Jolivet, M., Labaume, P., Monié, P., Brunel, M., Arnaud, N. and Campani, M., 2007. Thermochronology constraints for the propagation sequence of the south Pyrenean basement thrust system (France-Spain). Tectonics, 26(5): n/a-n/a.

Ke, X., Ji, J., Zhang, K., Kou, X., Song, B. and Wang, C., 2013. Magnetostratigraphy and Anisotropy of Magnetic Susceptibility of the Lulehe Formation in the Northeastern Qaidam Basin. Acta Geologica Sinica-English Edition, 87(2): 576-587.

Kohn, M.J., 2008. PTt data from central Nepal support critical taper and repudiate large-scale channel flow of the Greater Himalayan Sequence. Geological Society of America Bulletin, 120(3-4): 259-273.

Lallemand, S.E., Schnürle, P. and Malavieille, J., 1994. Coulomb theory applied to accretionary and nonaccretionary wedges: Possible causes for tectonic erosion and/or 
frontal accretion. Journal of Geophysical Research: Solid Earth, 99(B6): 12033-12055.

Lease, R.O., 2014. Cenozoic mountain building on the northeastern Tibetan Plateau. Geological Society of America Special Papers, 507: 115-127.

Lease, R.O., Ehlers, T.A. and Enkelmann, E., 2016. Large along-strike variations in the onset of Subandean exhumation: Implications for Central Andean orogenic growth. Earth and Planetary Science Letters, 451: 62-76.

Li, B., Chen, X., Zuza, A.V., Hu, D., Ding, W., Huang, P. and Xu, S.J.T., 2019. Cenozoic cooling history of the North Qilian Shan, northern Tibetan Plateau, and the initiation of the Haiyuan fault: Constraints from apatite-and zircon-fission track thermochronology. Tectonophysics, 751: 109-124.

Li, J., Yue, L., Roberts, A., Hirt, A.M., Pan, F., Guo, L., Xu, Y., Xi, R., Guo, L. and Qiang, X., 2018. Global cooling and enhanced Eocene Asian mid-latitude interior aridity. Nature communications, 9(1): 3026.

Li, L., Garzione, C.N., Pullen, A. and Chang, H., 2016. Early-middle Miocene topographic growth of the northern Tibetan Plateau: Stable isotope and sedimentation evidence from the southwestern Qaidam basin. Palaeogeography, Palaeoclimatology, Palaeoecology, 461: 201-213.

Li, L.-L., Wu, C.-D., Fan, C.-F., Li, J.-J. and Zhang, C.-H., 2017. Carbon and oxygen isotopic constraints on paleoclimate and paleoelevation of the southwestern Qaidam basin, northern Tibetan Plateau. Geoscience Frontiers, 8(5): 1175-1186.

Licht, A., Dupont-Nivet, G., Pullen, A., Kapp, P., Abels, H., Lai, Z., Guo, Z., Abell, J. and Giesler, D., 2016. Resilience of the Asian atmospheric circulation shown by Paleogene dust provenance. Nature Communications, 7.

Liu, D., Li, H., Sun, Z., Pan, J., Wang, M., Wang, H. and Marie, L., 2017. AFT dating constrains the Cenozoic uplift of the Qimen Tagh Mountains, Northeast Tibetan 
Plateau, comparison with LA-ICPMS Zircon U-Pb ages. Gondwana Research, 41: 438-450.

Liu, D., Yan, M., Fang, X., Li, H., Song, C. and Dai, S., 2011a. Magnetostratigraphy of sediments from the Yumu Shan, Hexi Corridor and its implications regarding the Late Cenozoic uplift of the NE Tibetan Plateau. Quaternary international, 236(1-2): 13-20.

Liu, X., 2017. Characteristics of active tectonics and the deformation pattern of the Jiuxi basin at the western Qilian Shan, Lanzhou University, Lanzhou, 1-122 pp.

Liu, Y.-S., Utescher, T., Zhou, Z. and Sun, B., 2011b. The evolution of Miocene climates in North China: Preliminary results of quantitative reconstructions from plant fossil records. Palaeogeography, Palaeoclimatology, Palaeoecology, 304(3): 308-317.

Liu - Zeng, J., Tapponnier, P., Gaudemer, Y. and Ding, L., 2008. Quantifying landscape differences across the Tibetan plateau: Implications for topographic relief evolution. Journal of Geophysical Research: Earth Surface, 113(F4).

Lu, H., Wang, X., Wang, X., Chang, X., Zhang, H., Xu, Z., Zhang, W., Wei, H., Zhang, X. and Yi, S.J.E.-S.R., 2019. Formation and evolution of Gobi Desert in central and eastern Asia乞s. Earth-Science Reviews, 194: 251-263.

Lu, H. and Xiong, S., 2009. Magnetostratigraphy of the Dahonggou section, northern Qaidam Basin and its bearing on Cenozoic tectonic evolution of the Qilian Shan and Altyn Tagh Fault. Earth and Planetary Science Letters, 288(3): 539-550.

Malavieille, J., 2010. Impact of erosion, sedimentation, and structural heritage on the structure and kinematics of orogenic wedges: Analog models and case studies. GSA Today, 20(1): 4-10.

Malavieille, J., Molli, G., Genti, M., Dominguez, S., Beyssac, O., Taboada, A., VitaleBrovarone, A., Lu, C.-Y. and Chen, C.-T., 2016. Formation of ophiolite-bearing tectono-sedimentary mélanges in accretionary wedges by gravity driven submarine 
erosion: Insights from analogue models and case studies. Journal of Geodynamics, 100: $87-103$.

Mao, L., Yi, H., Ji, C. and Xia, G., 2014. Petrography and Carbon-Oxygen Isotope Characteristics of the Cenozoic Lacustrine Carbonate Rocks in Qaidam Basin. Geological Science and Technology Information, 33(1): 41-48.

Masek, J.G., Isacks, B.L., Gubbels, T.L. and Fielding, E., 1994. Erosion and tectonics at the margins of continental plateaus. Journal of Geophysical Research: Solid Earth, 99(B7): 13941-13956.

McRivette, M.W., Yin, A., Chen, X. and Gehrels, G.E., 2019. Cenozoic basin evolution of the central Tibetan plateau as constrained by U-Pb detrital zircon geochronology, sandstone petrology, and fission-track thermochronology. Tectonophysics, 751: 150179.

Meng, Q.R. and Fang, X., 2008. Cenozoic tectonic development of the Qaidam Bas in in the northeastern Tibetan Plateau. Geological Society of America Special Papers, 444: 124.

Métivier, F., Gaudemer, Y., Tapponnier, P. and Meyer, B., 1998. Northeastward growth of the Tibet plateau deduced from balanced reconstruction of two depositio nal areas: The Qaidam and Hexi Corridor basins, China. Tectonics, 17(6): 823-842.

Meyer, B., Tapponnier, P., Bourjot, L., Metivier, F., Gaudemer, Y., Peltzer, G., Shunmin, G. and Zhitai, C., 1998. Crustal thickening in Gansu - Qinghai, lithospheric mantle subduction, and oblique, strike - slip controlled growth of the Tibet plateau. Geophysical Journal International, 135(1): 1-47.

Molnar, P., England, P. and Martinod, J., 1993. Mantle dynamics, uplift of the Tibetan Plateau, and the Indian monsoon. Reviews of Geophysics, 31(4): 357-396.

Montgomery, D.R., Balco, G. and Willett, S.D., 2001. Climate, tectonics, and the 
morphology of the Andes. Geology, 29(7): 579-582.

$\mathrm{Mu}, \mathrm{J} ., 2002$. The features of tertiary sequence stratigraphy and their controlling factors in the Hong-Shi area of Qaidam basin, China University of Geosciences (Beijing), 163 pp. Najman, Y., Appel, E., Boudagher-Fadel, M., Bown, P., Carter, A., Garzanti, E., Godin, L., Han, J., Liebke, U., Oliver, G., Parrish, R. and Vezzoli, G., 2010. Timing of IndiaAsia collision: Geological, biostratigraphic, and palaeomagnetic constraints. Journal of Geophysical Research: Solid Earth, 115(B12416).

Palumbo, L., Hetzel, R., Tao, M., Li, X. and Guo, J., 2009. Deciphering the rate of mountain growth during topographic presteady state: An example from the NE margin of the Tibetan Plateau. Tectonics, 28(4).

Pan, B., Li, Q., Hu, X., Geng, H., Liu, Z., Jiang, S. and Yuan, W., 2013. Cretaceous and Cenozoic cooling history of the eastern Qilian Shan, north-eastern margin of the Tibetan Plateau: evidence from apatite fission-track analysis. Terra Nova, 25(6): 431438.

Pang, J., Yu, J., Zheng, D., Wang, W., Ma, Y., Wang, Y., Li, C., Li, Y. and Wang, Y., 2019a. Neogene expansion of the Qilian Shan, north Tibet: Implications for the dynamic evolution of the Tibetan Plateau. Tectonics.

Pang, J., Yu, J., Zheng, D., Wang, Y., Zhang, H., Li, C., Wang, W. and Hao, Y., 2019b. Constraints of new apatite fission-track ages on the tectonic pattern and geomorphic development of the northern margin of the Tibetan Plateau. Journal of Asian Earth Sciences, 181: 103909.

Qi, B., Hu, D., Yang, X., Zhang, Y., Tan, C., Zhang, P. and Feng, C., 2016a. Apatite fission track evidence for the Cretaceous-Cenozoic cooling history of the Qilian Shan (NW China) and for stepwise northeastward growth of the northeastern Tibetan Plateau since early Eocene. Journal of Asian Earth Sciences, 124: 28-41. 
Qi, B., Hu, D., Yang, X., Zhang, Y., Tan, C., Zhang, P. and Feng, C., 2016b. Apatite Fission Track Study of the Cretaceous-Cenozoic Stepwise Uplift of the Middle Segment of the Qilian Mountain. Acta Geoscientica Sinica, 37(1): 46-58.

Qiang, X., An, Z., Song, Y., Chang, H., Sun, Y., Liu, W., Ao, H., Dong, J., Fu, C., Wu, F., Lu, F., Cai, Y., Zhou, W., Cao, J., Xu, X. and Ai, L., 2011. New eolian red clay sequence on the western Chinese Loess Plateau linked to onset of Asian desertification about 25 Ma ago. Science China Earth Sciences, 54(1): 136-144.

Rieser, A.B., Bojar, A.-V., Neubauer, F., Genser, J., Liu, Y., Ge, X.-H. and Fried1, G., 2009. Monitoring Cenozoic climate evolution of northeastern Tibet: stable isotope constraints from the western Qaidam Basin, China. International Journal of Earth Sciences, 98(5): 1063-1075.

Ritts, B.D. and Biffi, U., 2000. Magnitude of post-Middle Jurassic (Bajocian) displacement on the central Altyn Tagh fault system, northwest China. Geological Society of America Bulletin, 112(1): 61-74.

Ritts, B.D., Yue, Y. and Graham, S.A., 2004. Oligocene - Miocene Tectonics and Sedimentation along the Altyn Tagh Fault, Northern Tibetan Plateau: Analysis of the Xorkol, Subei, and Aksay Basins. The Journal of geology, 112(2): 207-229.

Roe, G.H., Whipple, K.X. and Fletcher, J.K., 2008. Feedbacks among climate, erosion, and tectonics in a critical wedge orogen. American Journal of Science, 308(7): 815-842.

Searle, M., Avouac, J.-P., Elliott, J. and Dyck, B., 2017. Ductile shearing to brittle thrusting along the Nepal Himalaya: Linking Miocene channel flow and critical wedge tectonics to 25th April 2015 Gorkha earthquake. Tectonophysics, 714-715: 117-124.

Song, C., Fang, X., Li, J., Gao, J., Zhao, Z. and Fan, M., 2001. Tectonic uplift and sedimentary evolution of the Jiuxi Basin in the northern margin of the Tibetan Plateau since 13 Ma BP. Science in China Series D-Earth Sciences, 44(1): 192-202. 
Staisch, L.M., Niemi, N.A., Hong, C., Clark, M.K., Rowley, D.B. and Currie, B., 2014. A Cretaceous - Eocene depositional age for the Fenghuoshan Group, Hoh Xil Basin: Implications for the tectonic evolution of the northern Tibet Plateau. Tectonics, 33(3): 281-301.

Stockmal, G.S., 1983. Modeling of large - scale accretionary wedge deformation. Journal of Geophysical Research: Solid Earth, 88(B10): 8271-8287.

Sun, G., Liu, W., Wang, B., Xu, L., Kang, J. and Wang, H., 2016. Reservoir Characteristics of the Lulehe Formation in the Pingtai Area of the northern Qaidam basin. Acta Sedimentologica Sinica, 34(2): 356-363.

Sun, J., Ye, J., Wu, W., Ni, X., Bi, S., Zhang, Z., Liu, W. and Meng, J., 2010. Late Oligocene-Miocene mid-latitude aridification and wind patterns in the Asian interior. Geology, 38(6): 515-518.

Suppe, J. and Medwedeff, D.A., 1990. Geometry and kinematics of fault-propagation folding. Eclogae Geologicae Helvetiae, 83(3): 409-454.

Vermeesch, P., 2013. Multi-sample comparison of detrital age distributions. Chemical Geology, 341: 140-146.

Wang, E., Xu, F.-Y., Zhou, J.-X., Wan, J. and Burchfiel, B.C., 2006. Eastward migration of the Qaidam basin and its implications for Cenozoic evolution of the Altyn Tagh fault and associated river systems. Geological Society of America Bulletin, 118(3-4): 349365.

Wang, F., Shi, W., Zhang, W., Wu, L., Yang, L., Wang, Y. and Zhu, R., 2017a. Differential growth of the northern Tibetan margin: evidence for oblique stepwise rise of the Tibetan Plateau. Scientific Reports, 7: 41164.

Wang, W., Zhang, P., Pang, J., Garzione, C., Zhang, H., Liu, C., Zheng, D., Zheng, W. and Yu, J., 2016a. The Cenozoic growth of the Qilian Shan in the northeastern Tibetan 
Plateau: A sedimentary archive from the Jiuxi Basin. Journal of Geophysical Research: Solid Earth, 121(4): 2235-2257.

Wang, W., Zhang, P., Yu, J., Wang, Y., Zheng, D., Zheng, W., Zhang, H. and Pang, J., 2016b. Constraints on mountain building in the northeastern Tibet: Detrital zircon records from synorogenic deposits in the Yumen Basin. Scientific Reports, 6: 27604.

Wang, W., Zheng, W., Zhang, P., Li, Q., Kirby, E., Yuan, D., Zheng, D., Liu, C., Wang, Z. and Zhang, H., 2017b. Expansion of the Tibetan Plateau during the Neogene. Nature communications, 8: 15887.

Wang, X., Deng, L., Zattin, M., Ji, M. and Li, J., 2017c. Palaeogene growth of the northeastern Tibetan Plateau: Detrital fission track and sedimentary analysis of the Lanzhou basin, NW China. Journal of Asian Earth Sciences, 147: 322-331.

Wang, X., Sun, D., Chen, F., Wang, F., Li, B., Popov, S.V., Wu, S., Zhang, Y. and Li, Z., 2014. Cenozoic paleo-environmental evolution of the Pamir-Tien Shan convergence zone. Journal of Asian Earth Sciences, 80: 84-100.

Wang, Y., Zheng, D., Pang, J., Zhang, H., Wang, W., Yu, J., Zhang, Z., Zheng, W., Zhang, P. and Li, Y., 2018. Using slope-area and apatite fission track analysis to decipher the rock uplift pattern of the Yumu Shan: New insights into the growth of the NE Tibetan Plateau. Geomorphology, 308: 118-128.

Whipple, K.X., 2009. The influence of climate on the tectonic evolution of mountain belts. Nature geoscience, 2(2): 97.

Willett, S.D., 1999. Orogeny and orography: The effects of erosion on the structure of mountain belts. Journal of Geophysical Research: Solid Earth, 104(B12): 2895728981.

Wu, C., Yin, A., Zuza, A.V., Zhang, J., Liu, W. and Ding, L., 2016. Pre-Cenozoic geologic history of the central and northern Tibetan Plateau and the role of Wilson cycles in 
constructing the Tethyan orogenic system. Lithosphere, 8(3): 254-292.

Wu, L., Xiao, A., Wang, L., Mao, L., Wang, L., Dong, Y. and Xu, B., 2012a. EW-trending uplifts along the southern side of the central segment of the Altyn Tagh Fault, NW China: Insight into the rising mechanism of the Altyn Mountain during the Cenozoic. Science China Earth Sciences, 55(6): 926-939.

Wu, L., Xiao, A.C., Yang, S.F., Wang, L.Q., Mao, L.G., Wang, L., Dong, Y.P. and Xu, B., 2012b. Two - stage evolution of the Altyn Tagh Fault during the Cenozoic: new insight from provenance analysis of a geological section in NW Qaidam Basin, NW China. Terra Nova, 24(5): 387-395.

Xia, W.C., Zhang, N., Yuan, X.P., Fan, L.S. and Zhang, B.S., 2001. Cenozoic Qaidam basin, China: A stronger tectonic inversed, extensional rifted basin. AAPG bulletin, 85(4): $715-736$.

Yan, D.-F., Zhang, L., Han, L., Yang, T. and Chen, Y.-Q., 2018. Podocarpium from the Oligocene of NW Qaidam Basin, China and its implications. Review of Palaeobotany and Palynology, 259: 1-9.

Yang, T., Zhang, L., Li, W., Jia, J., Han, L., Zhang, Y., Chen, Y. and Yan, D., 2018. New schizothoracine from Oligocene of Qaidam Basin, northern Tibetan Plateau, China, and its significance. Journal of Vertebrate Paleontology, 38(2): e1442840.

Yin, A., Dang, Y.Q., Wang, L.C., Jiang, W.M., Zhou, S.P., Chen, X.H., Gehrels, G.E. and McRivette, M.W., 2008a. Cenozoic tectonic evolution of Qaidam basin and its surrounding regions (Part 1): The southern Qilian Shan-Nan Shan thrust belt and northern Qaidam basin. Geological Society of America Bulletin, 120(7-8): 813-846.

Yin, A., Dang, Y.Q., Zhang, M., Chen, X.H. and McRivette, M.W., 2008b. Cenozoic tectonic evolution of the Qaidam basin and its surrounding regions (Part 3): Structural geology, sedimentation, and regional tectonic reconstruction. Geological Society of America 
Bulletin, 120(7-8): 847-876.

Yin, A., Dang, Y.Q., Zhang, M., McRivette, M.W., Burgess, W.P. and Chen, X.H., 2007.

Cenozoic tectonic evolution of Qaidam basin and its surrounding regions (part 2):

Wedge tectonics in southern Qaidam basin and the Eastern Kunlun Range. Geological Society of America Special Papers, 433: 369-390.

Yin, A. and Harrison, T.M., 2000. Geologic evolution of the Himalayan-Tibetan orogen. Annual Review of Earth and Planetary Sciences, 28(1): 211-280.

Yin, A., Rumelhart, P., Butler, R., Cowgill, E., Harrison, T., Foster, D., Ingersoll, R., Qing, Z., Xian-Qiang, Z. and Xiao-Feng, W., 2002. Tectonic history of the Altyn Tagh fault system in northern Tibet inferred from Cenozoic sedimentation. Geological Society of America Bulletin, 114(10): 1257-1295.

Yu, J., Pang, J., Wang, Y., Zheng, D., Liu, C., Wang, W., Li, Y., Li, C. and Xiao, L., 2019. Mid-Miocene uplift of the northern Qilian Shan as a result of the northward growth of the northern Tibetan Plateau. Geosphere, 15(2): 423-432.

Yuan, D.-Y., Champagnac, J.-D., Ge, W.-P., Molnar, P., Zhang, P.-Z., Zheng, W.-J., Zhang, H.-P. and Liu, X.-W., 2011. Late Quaternary right-lateral slip rates of faults adjacent to the lake Qinghai, northeastern margin of the Tibetan Plateau. Geological Society of America Bulletin, 123(9-10): 2016-2030.

Yuan, D.Y., Ge, W.P., Chen, Z.W., Li, C.Y., Wang, Z.C., Zhang, H.P., Zhang, P.Z., Zheng, D.W., Zheng, W.J. and Craddock, W.H., 2013. The growth of northeastern Tibet and its relevance to large - scale continental geodynamics: A review of recent studies. Tectonics, 32(5): 1358-1370.

Yue, Y. and Liou, J., 1999. Two-stage evolution model for the Altyn Tagh fault, China. Geology, 27(3): 227-230.

Yue, Y.J., Ritts, B.D. and Graham, S.A., 2001. Initiation and long-term slip history of the 
Altyn Tagh Fault. International Geology Review, 43(12): 1087-1093.

Zachos, J., Pagani, M., Sloan, L., Thomas, E. and Billups, K., 2001. Trends, Rhythms, and Aberrations in Global Climate 65 Ma to Present. Science, 292(5517): 686-693.

Zhang, C., Cheng, F., Huang, G., Huang, Y., Xing, C., Guan, B., Zhang, Q. and Xu, G., 2013. Sediment and reservoir characteristics with reservoir evaluation of the Lulehe Formation in Qie 16 block of Kunbei oilfield in Qaidam Basin. Acta Petrologica Sinica, 29(8): 2883-2894.

Zhang, H., Zhang, P., Prush, V., Zheng, D., Zheng, W., Wang, W., Liu, C. and Ren, Z., 2017. Tectonic geomorphology of the Qilian Shan in the northeastern Tibetan Plateau: Insights into the plateau formation processes. Tectonophysics.

Zhang, H.P., Craddock, W.H., Lease, R.O., Wang, W.t., Yuan, D.Y., Zhang, P.Z., Molnar, P., Zheng, D.W. and Zheng, W.J., 2012a. Magnetostratigraphy of the Neogene Chaka basin and its implications for mountain building processes in the north - eastern Tibetan Plateau. Basin Research, 24(1): 31-50.

Zhang, J., Yin, A., Liu, W., Wu, F., Lin, D. and Grove, M., 2012b. Coupled U-Pb dating and Hf isotopic analysis of detrital zircon of modern river sand from the Yalu River (Yarlung Tsangpo) drainage system in southern Tibet: Constraints on the transport processes and evolution of Himalayan rivers. Geological Society of America Bulletin, 124(9-10): 1449-1473.

Zhang, J.-Y., Yin, A., Liu, W.-C., Ding, L. and Xu, X.-M.J.L., 2016. First geomorphological and sedimentological evidence for the combined tectonic and climate control on Quaternary Yarlung river diversion in the eastern Himalaya. Lithosphere, 8(3): 293 316.

Zhang, Y., Sun, D., Li, Z., Wang, F., Wang, X., Li, B., Guo, F. and Wu, S., 2014. Cenozoic record of aeolian sediment accumulation and aridification from Lanzhou, China, 
driven by Tibetan Plateau uplift and global climate. Global and Planetary Change, 120: $1-15$

Zhao, Z., Fang, X. and Li, J., 2001. Late Cenozoic magnetic polarity stratigraphy in the Jiudong Basin, northern Qilian Mountain. Science in China Series D: Earth Sciences, 44(1): 243-250.

Zheng, D., Clark, M.K., Zhang, P., Zheng, W. and Farley, K.A., 2010. Erosion, fault initiation and topographic growth of the North Qilian Shan (northern Tibetan Plateau). Geosphere, 6(6): 937-941.

Zheng, D., Wang, W., Wan, J., Yuan, D., Liu, C., Zheng, W., Zhang, H., Pang, J. and Zhang, P., 2017. Progressive northward growth of the northern Qilian Shan-Hexi Corridor (northeastern Tibet) during the Cenozoic. Lithosphere, 9(3): 408-416.

Zheng, H., 2016. Asia dust production ramped up since latest Oligocene driven by Tibetan Plateau uplift. National Science Review, 3(3): 271-274.

Zheng, H., Wei, X., Tada, R., Clift, P.D., Wang, B., Jourdan, F., Wang, P. and He, M., 2015. Late oligocene-early miocene birth of the Taklimakan Desert. Proceedings of the National Academy of Sciences, 112(25): 7662-7667.

Zheng, W., Zhang, H.P., Zhang, P.Z., Molnar, P., Liu, X.W. and Yuan, D.Y., 2013a. Late Quaternary slip rates of the thrust faults in western Hexi Corridor (Northern Qilian Shan, China) and their implications for northeastward growth of the Tibetan Plateau. Geosphere, 9(2): 342-354.

Zheng, W., Zhang, P., He, W., Yuan, D., Shao, Y., Zheng, D., Ge, W.-p. and Min, W., 2013b. Transformation of displacement between strike-slip and crustal shortening in the northern margin of the Tibetan Plateau: Evidence from decadal GPS measurements and late Quaternary slip rates on faults. Tectonophysics, 584: 267-280.

Zheng, W.J., Zhang, P.Z., Ge, W.P., Molnar, P., Zhang, H.P., Yuan, D.Y. and Liu, J.H., 
2013c. Late Quaternary slip rate of the South Heli Shan Fault (northern Hexi Corridor, NW China) and its implications for northeastward growth of the Tibetan Plateau. Tectonics, 32(2): 271-293.

Zhou, H., Chen, L., Diwu, C. and Lei, C., 2018. Cenozoic uplift of the Qimantage Mountains, northeastern Tibet: Contraints from provenance analysis of Cenozoic sediments in Qaidam Basin. Geological Journal.

Zhuang, G., Hourigan, J.K., Koch, P.L., Ritts, B.D. and Kent-Corson, M.L., 2011a. Isotopic constraints on intensified aridity in Central Asia around 12Ma. Earth and Planetary Science Letters, 312(1): 152-163.

Zhuang, G., Hourigan, J.K., Ritts, B.D. and Kent-Corson, M.L., 2011b. Cenozoic multiplephase tectonic evolution of the northern Tibetan Plateau: Constraints from sedimentary records from Qaidam basin, Hexi Corridor, and Subei basin, northwest China. American Journal of Science, 311(2): 116-152.

Zou, N., Zhang, D., Long, G., Zhang, S., Lu, X., Jiang, H. and Shi, J., 2015. Sedimentary system evolution of Tertiary reservoirs in northern Qaidam Basin, China. Journal of Chengdu University of Technology (Science \& Technology Edition), 42(2): 149-158.

Zuza, A.V., Cheng, X. and Yin, A., 2016. Testing models of Tibetan Plateau formation with Cenozoic shortening estimates across the Qilian Shan-Nan Shan thrust belt. Geosphere, 12(2): 501-532.

Zuza, A.V., Levy, D.A., Wu, C., Li, B., Chen, X., Wang, Z. and Xiong, X., 2018 a. Underthrusting and duplexing beneath the northern Tibetan Plateau and the evolution of the Himalayan-Tibetan orogen. Lithosphere.

Zuza, A.V., Wu, C., Reith, R.C., Yin, A., Li, J., Zhang, J., Zhang, Y., Wu, L. and Liu, W., 2017. Tectonic evolution of the Qilian Shan: An early Paleozoic orogen reactivated in the Cenozoic. GSA Bulletin, 130(5-6): 881-925. 
Zuza, A.V., Wu, C., Reith, R.C., Yin, A., Li, J., Zhang, J., Zhang, Y., Wu, L. and Liu, W., 2018b. Tectonic evolution of the Qilian Shan: An early Paleozoic orogen reactivated in the Cenozoic. GSA Bulletin, 130(5-6): 881-925.

Zuza, A.V. and Yin, A., 2016. Continental deformation accommodated by non-rigid passive bookshelf faulting: An example from the Cenozoic tectonic development of northern Tibet. Tectonophysics, 677: 227-240.

Graphical abstract 


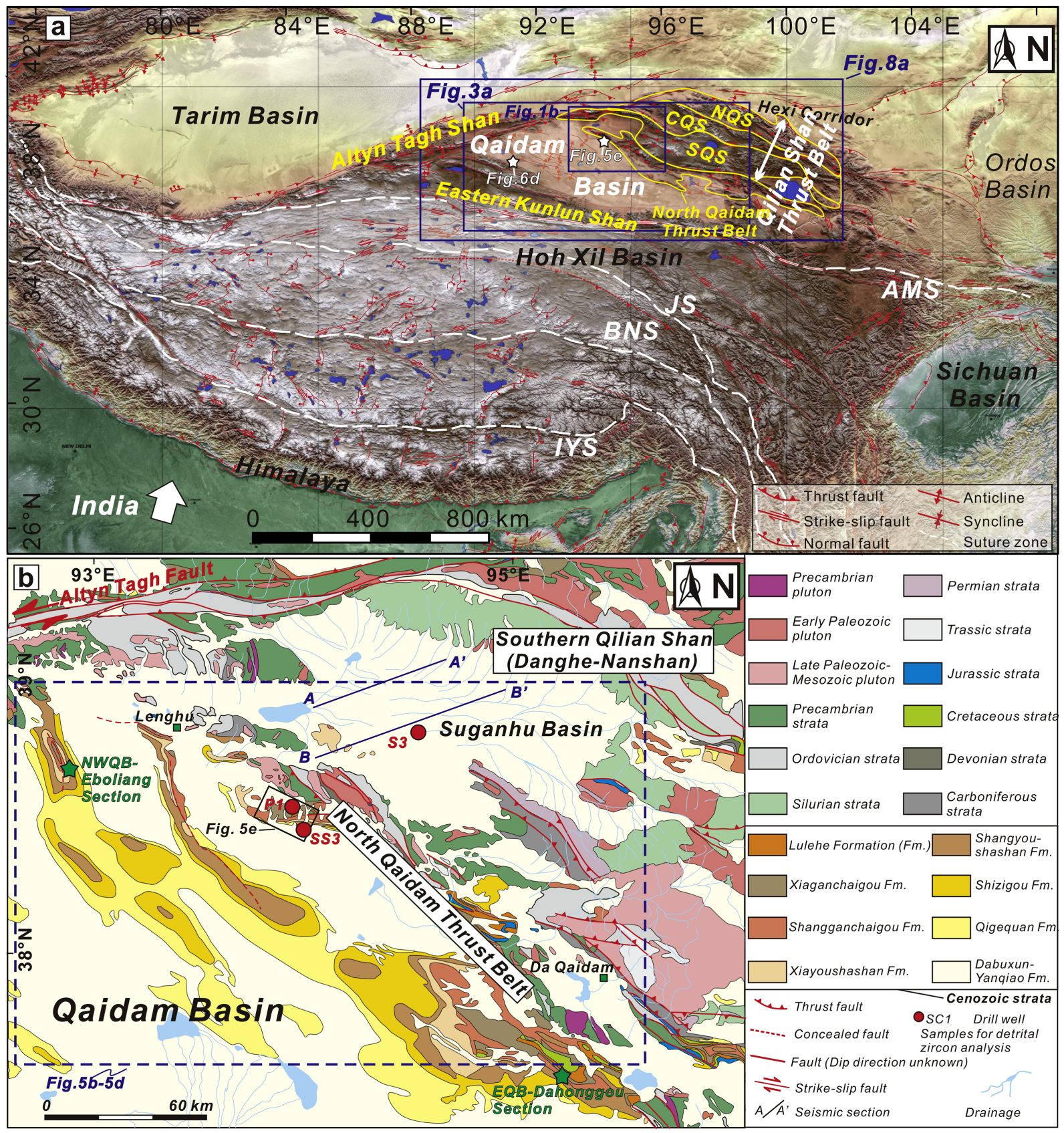

Figure 1 


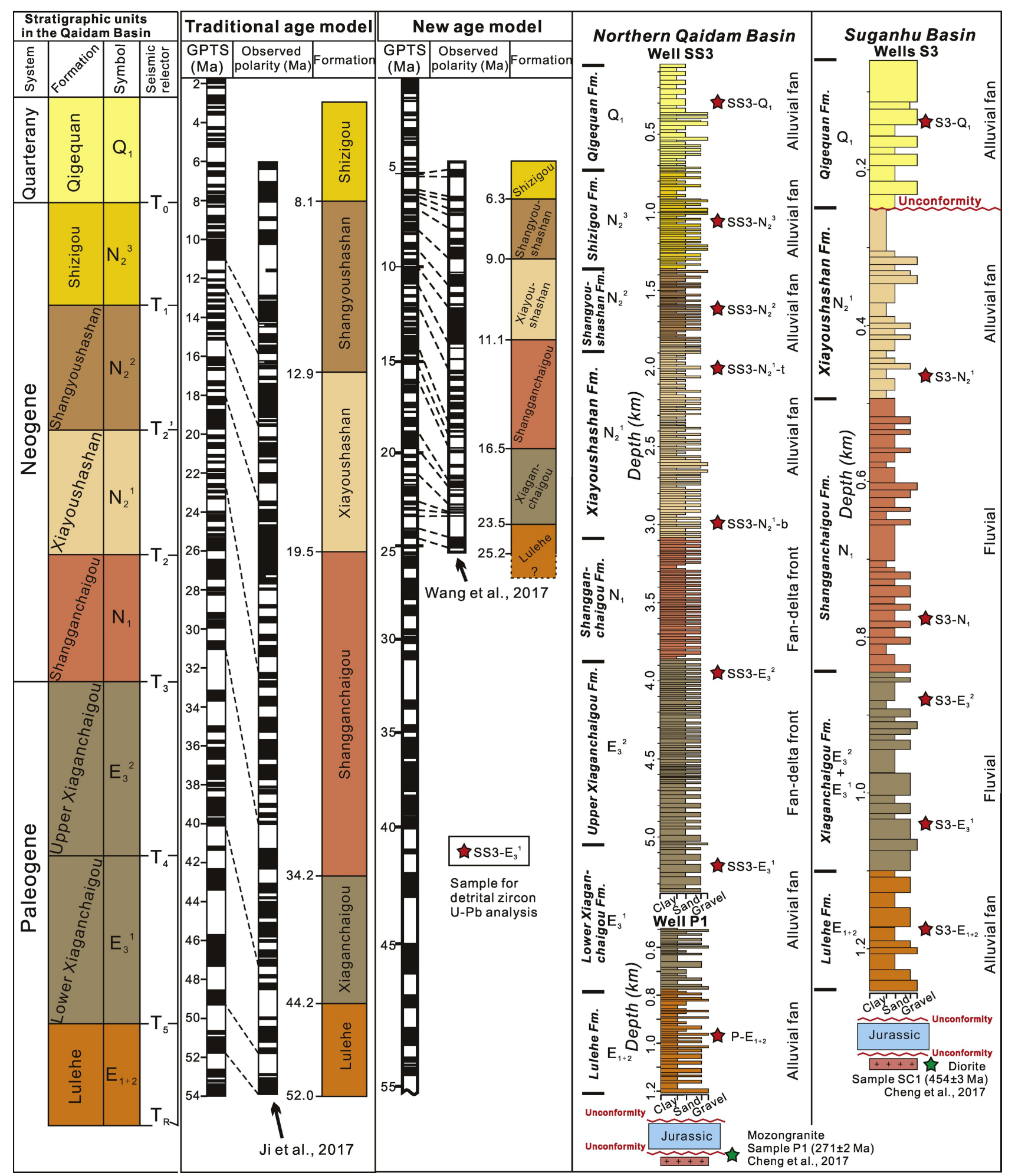

Figure 2 


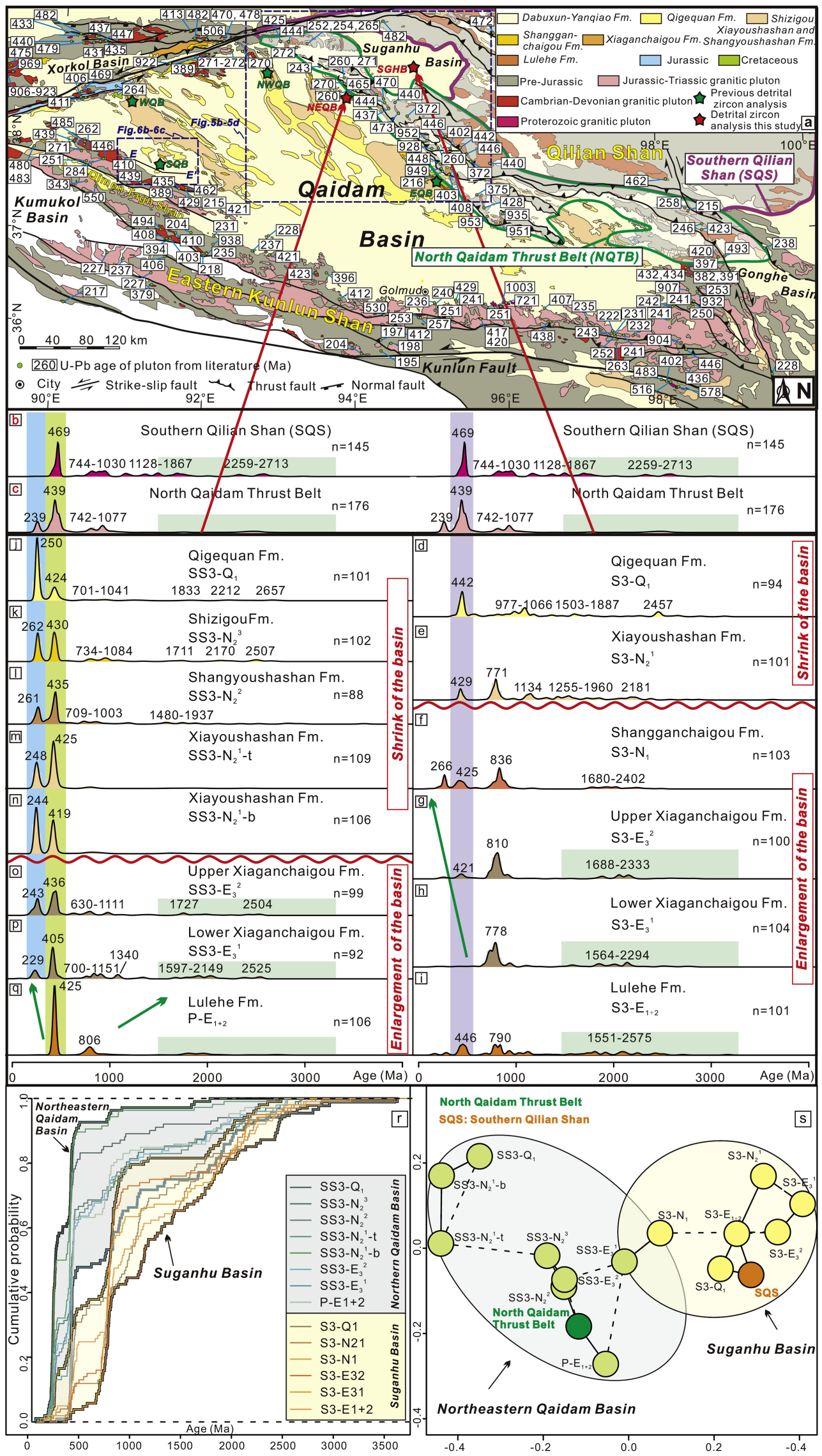



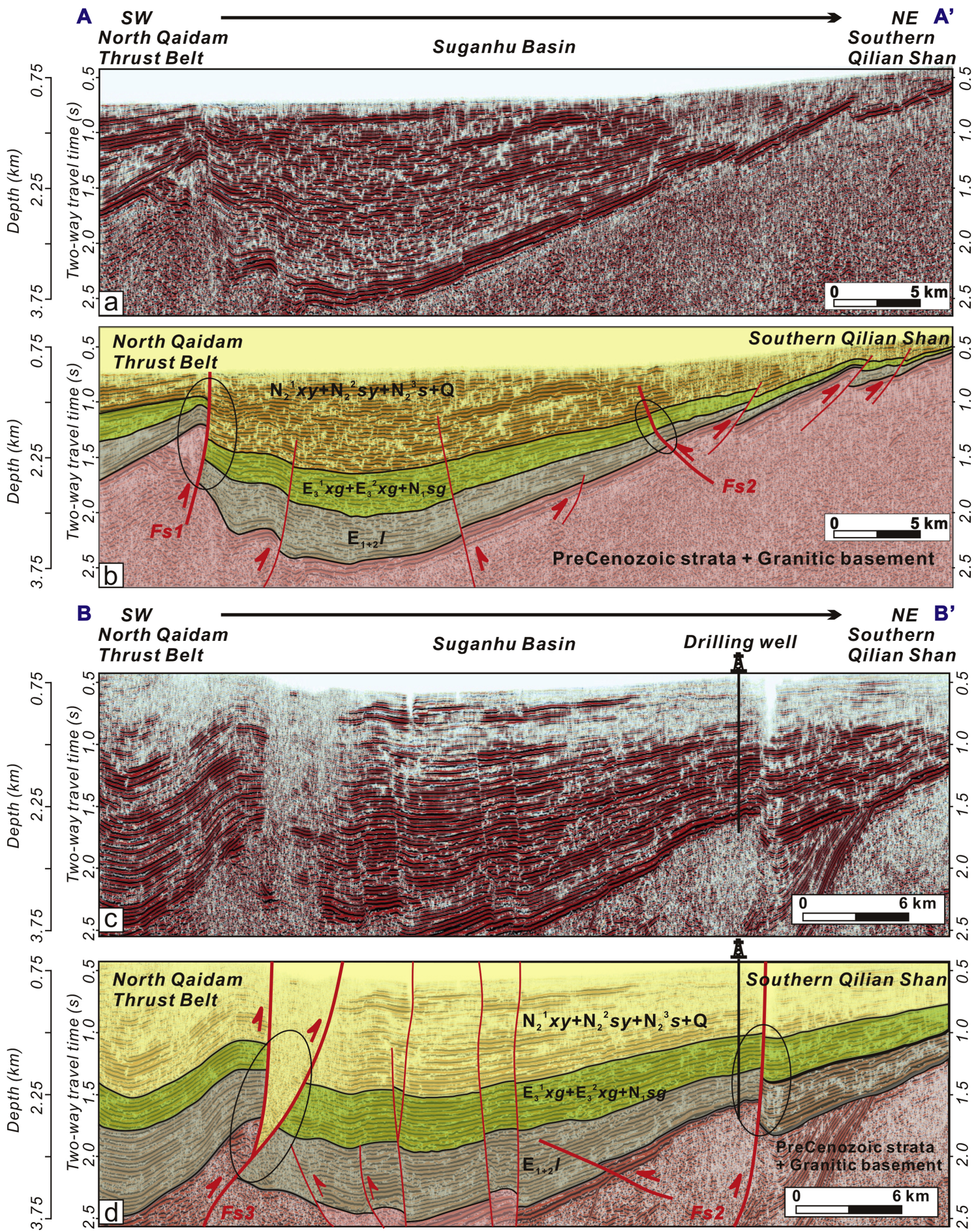
a

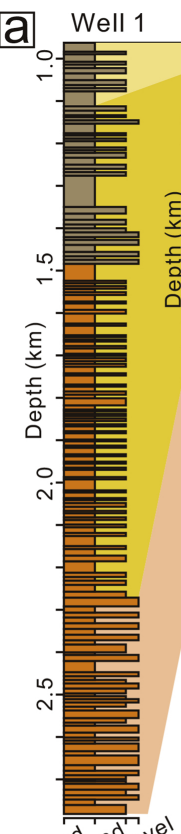

Well 2

Well 3

Well 4

Well 5
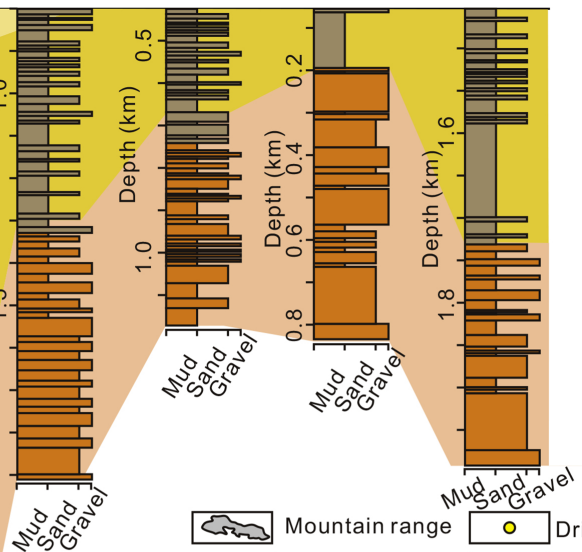

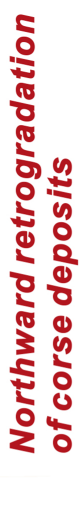

हत्य Mountain range 0 Drilling well

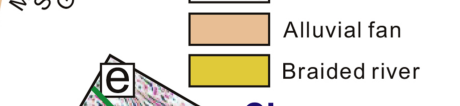

NuSang

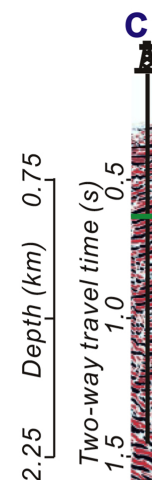

C sw

Time slice $(0.660 \mathrm{~s})$
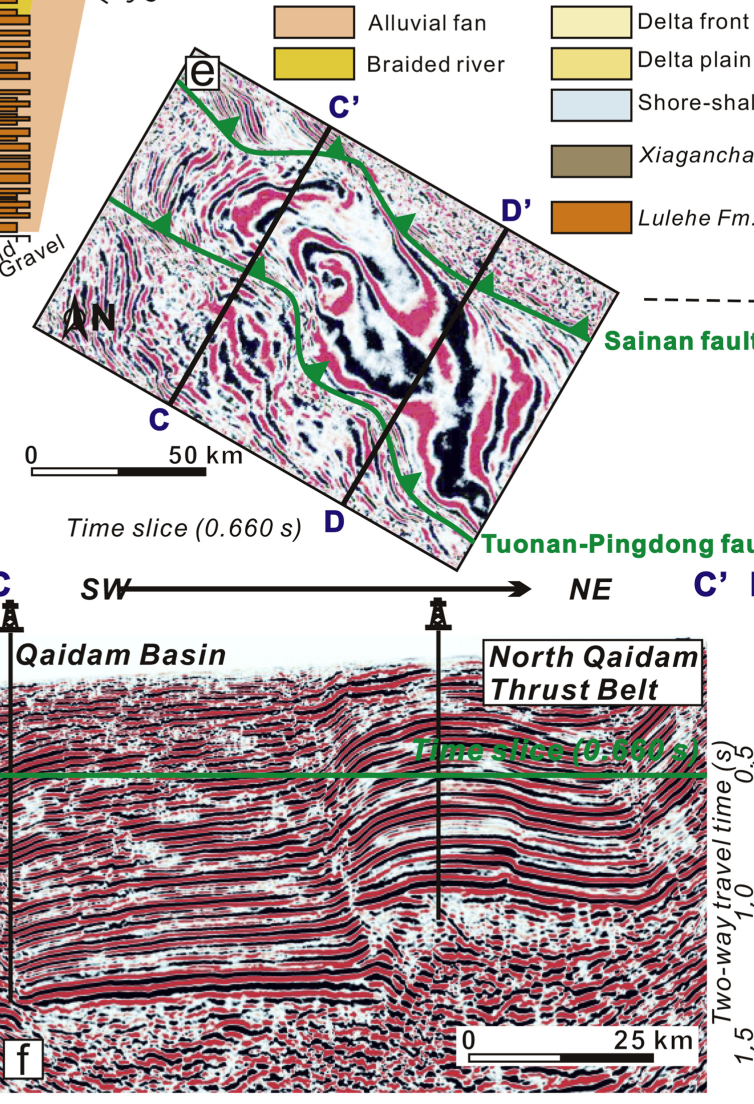

Shore-shallow lake

Xiaganchaigou Fm.

D' $\square$ Lulehe Fm.

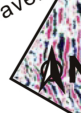

0

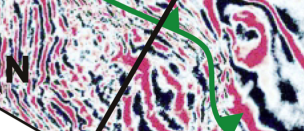

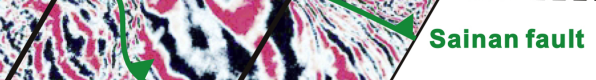

$50 \mathrm{~km}$

in 13

. Di) 3

D

34

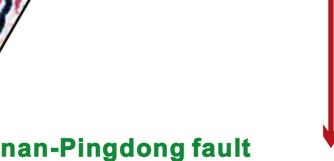

C'D $s w$

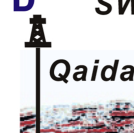

直

hathes

草$$
\text { م }
$$

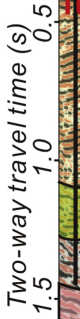

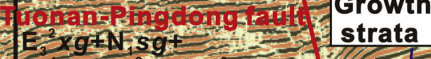
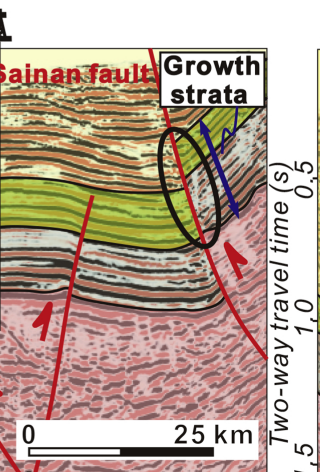

PreCenozoic strata + Granitic basement
Qaidam Basin

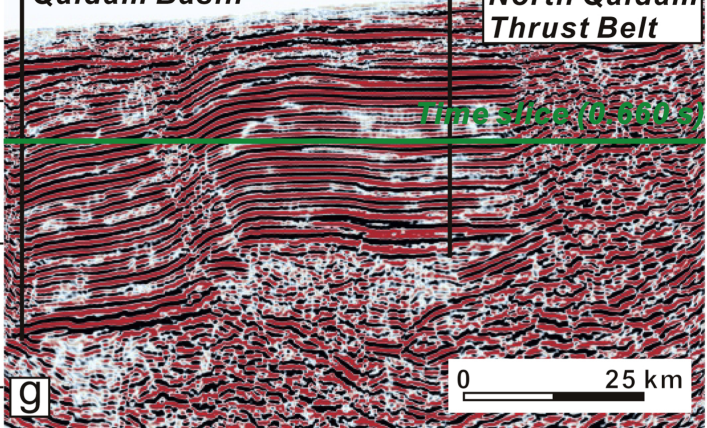

ba sugarhu $\Rightarrow$ Lulehe Fm.

b basti or

$\mathrm{E}_{1+2}$

N $4 \%$ Shan

QaidamBasin

0

C Sugandu $\Rightarrow$ Lower Xiaganchaigou Fm

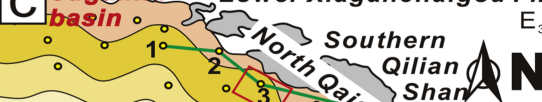

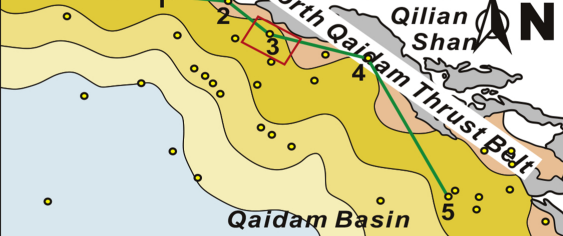

0

$80 \mathrm{~km}$
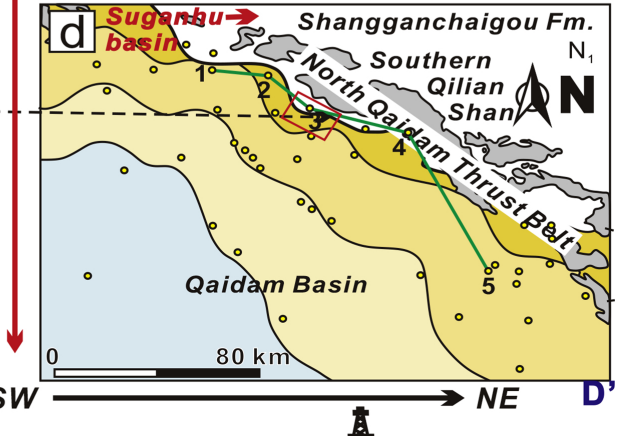

North Qaidam Thrust Belt

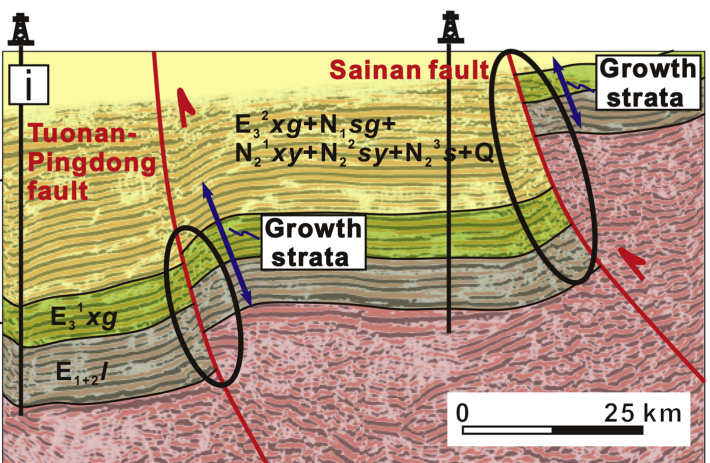

PreCenozoic strata + Granitic basement 


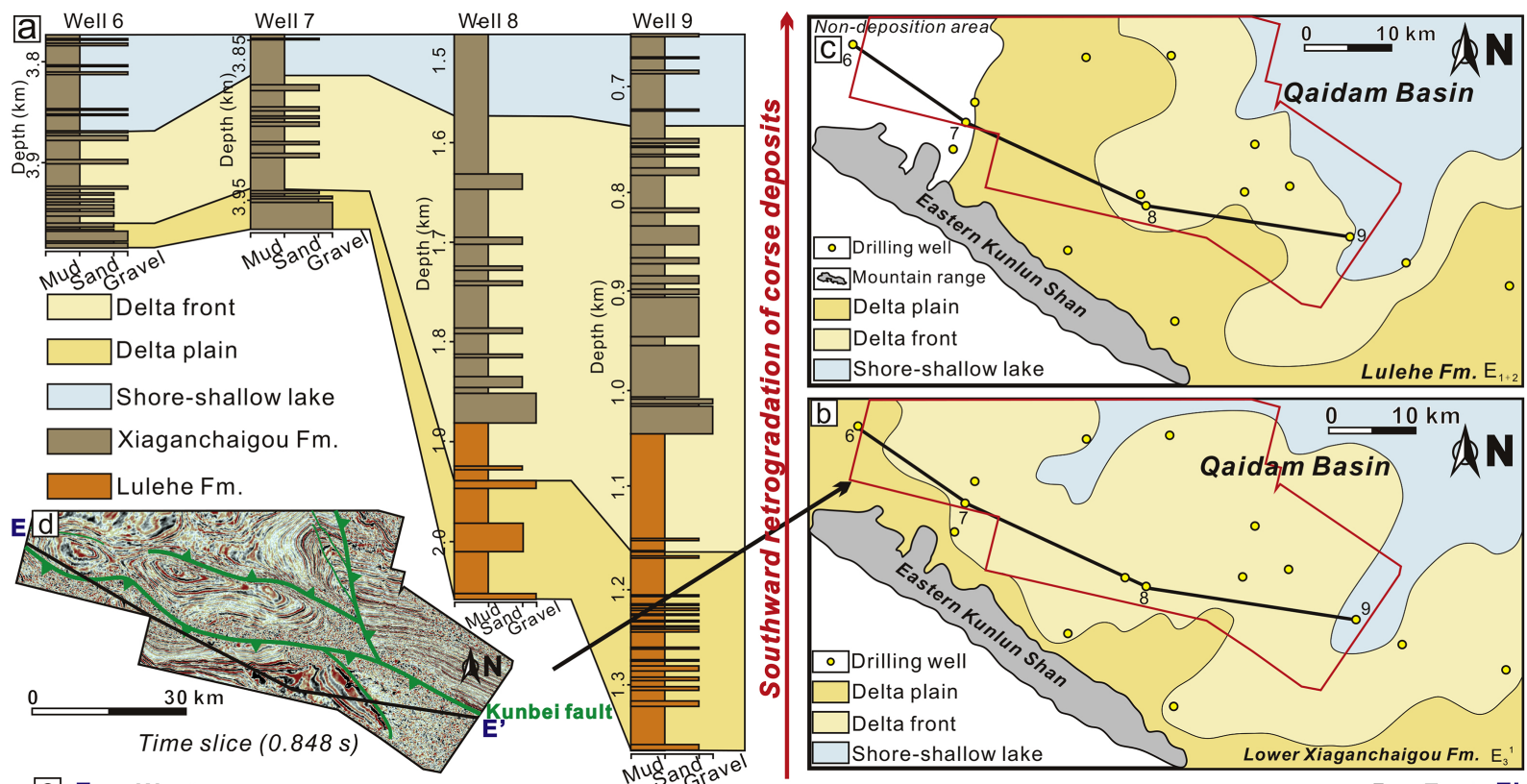

\section{e $\mathrm{E}$

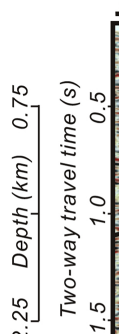

Time slice (0.848 s)

Muginarida

亩

亶

East $\mathrm{E}^{\prime}$

f

ifis

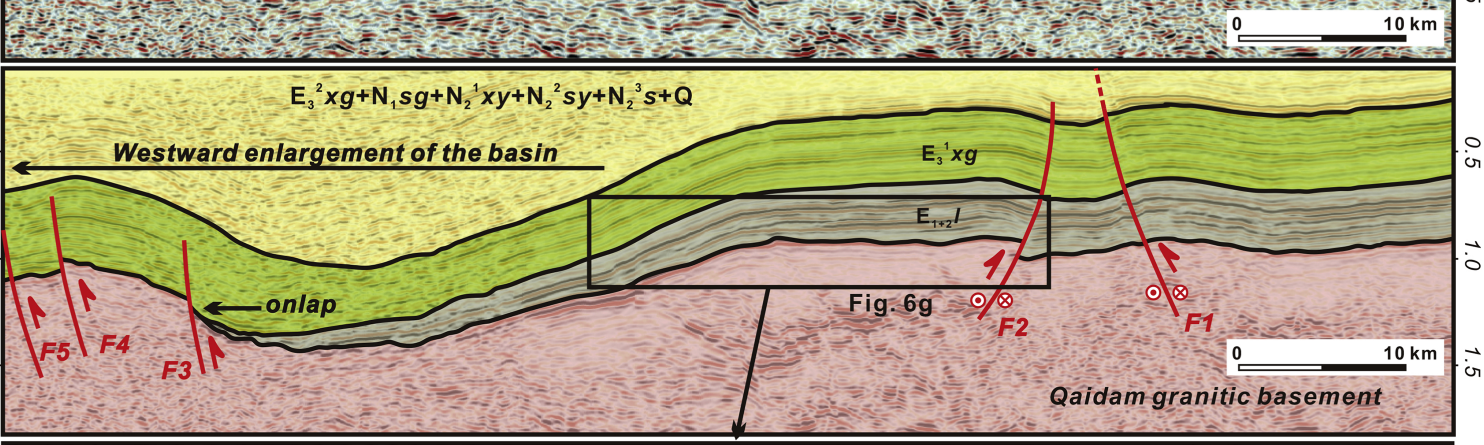

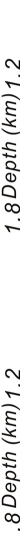

g]

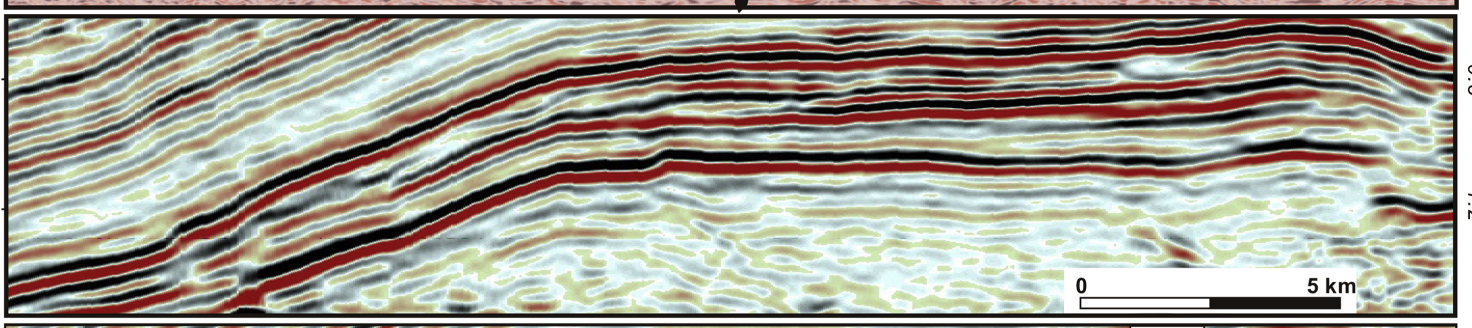

h

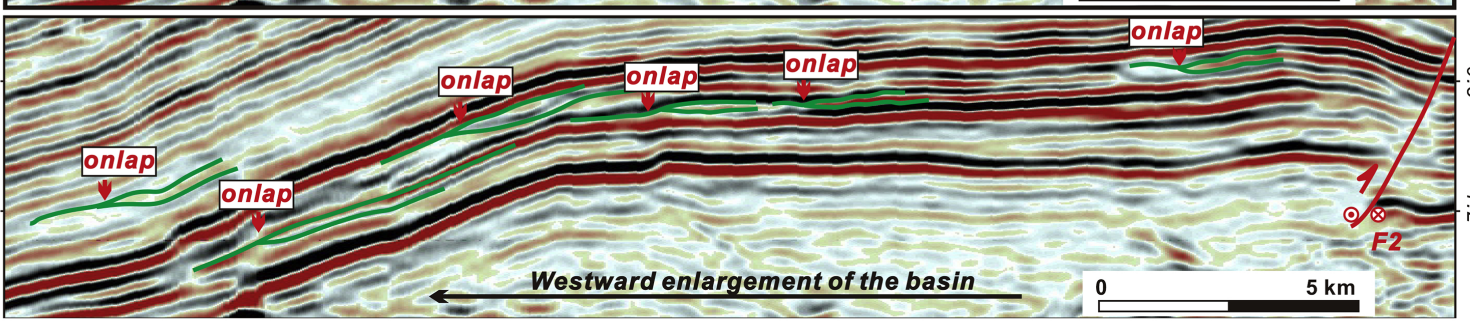




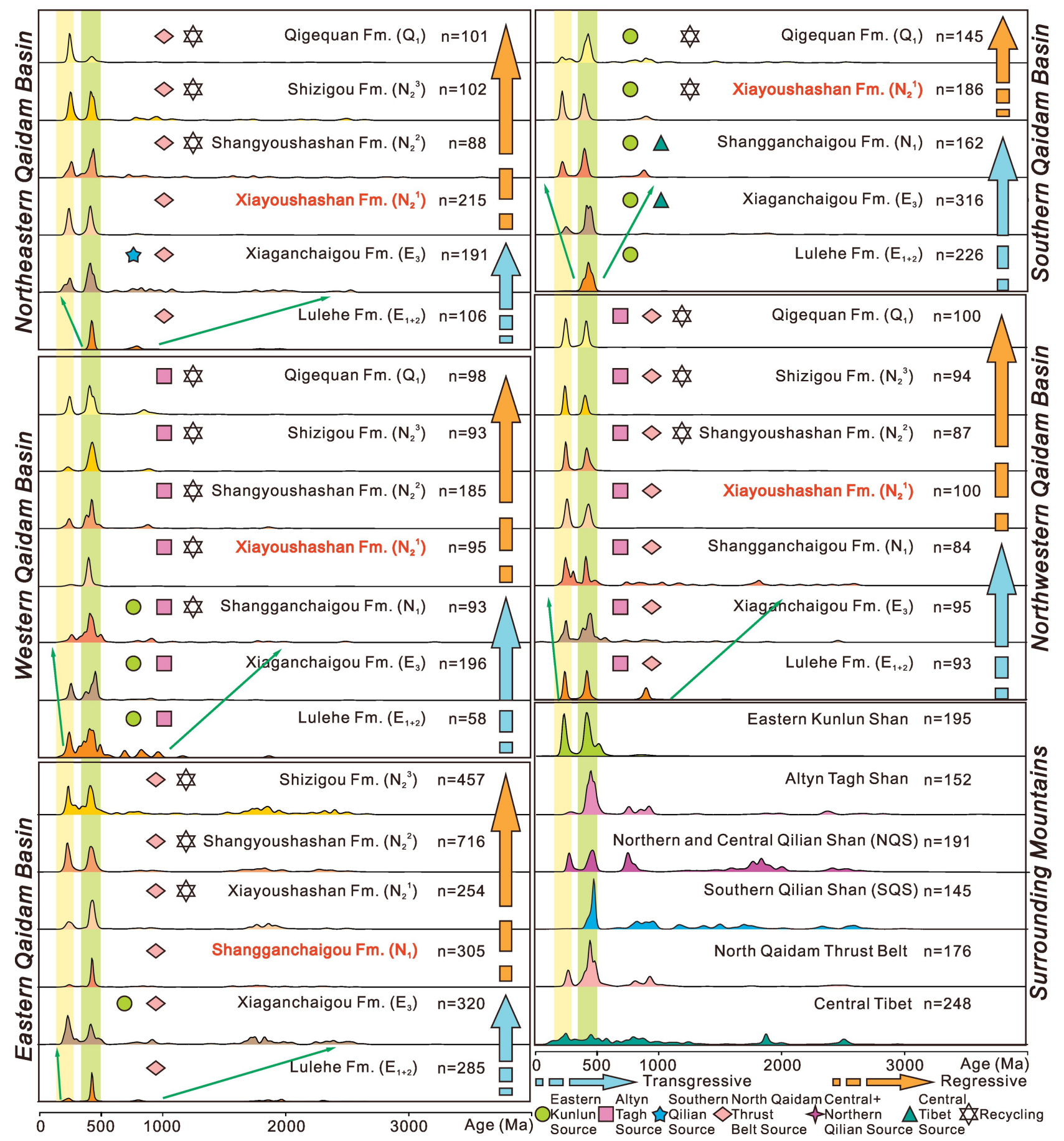

Figure 7 


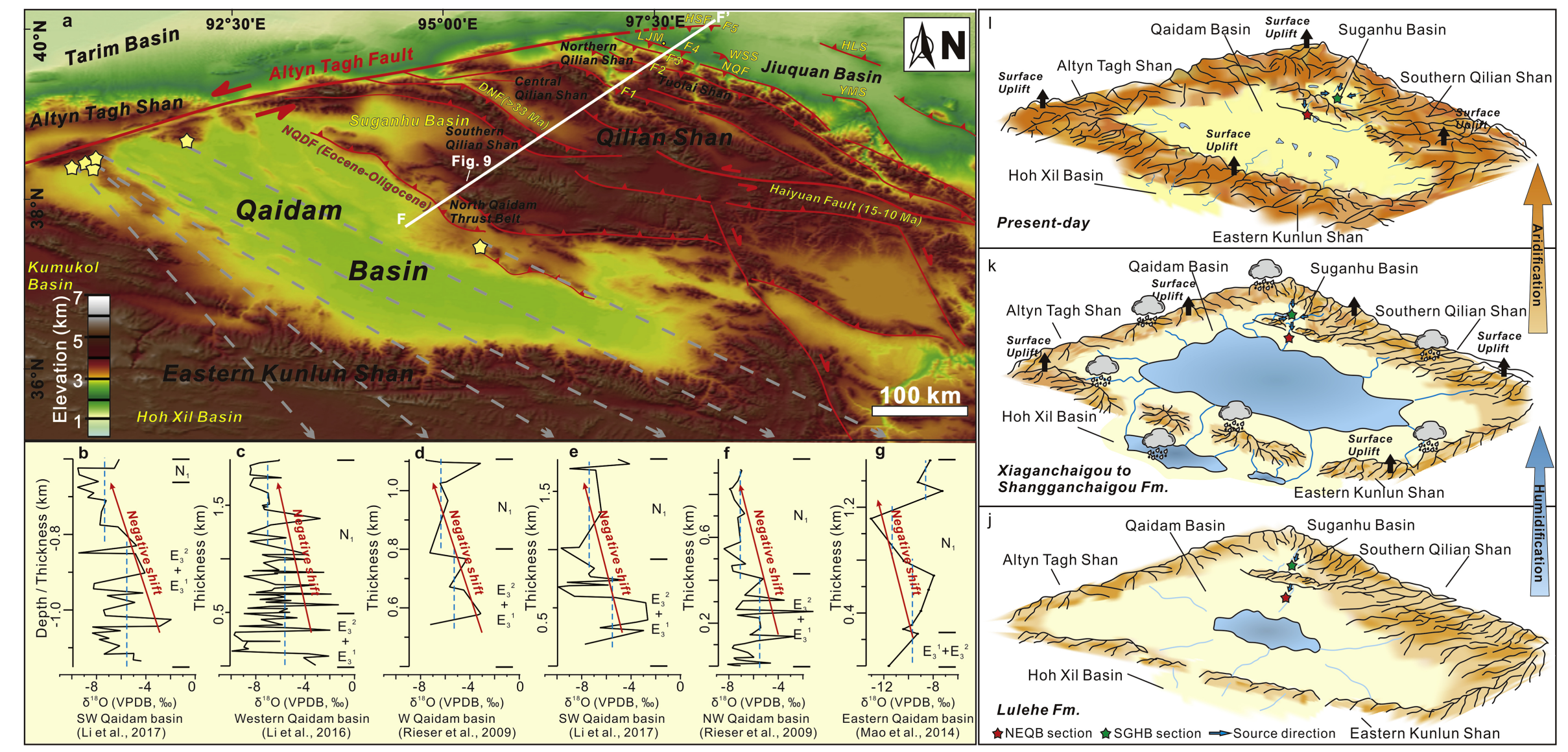




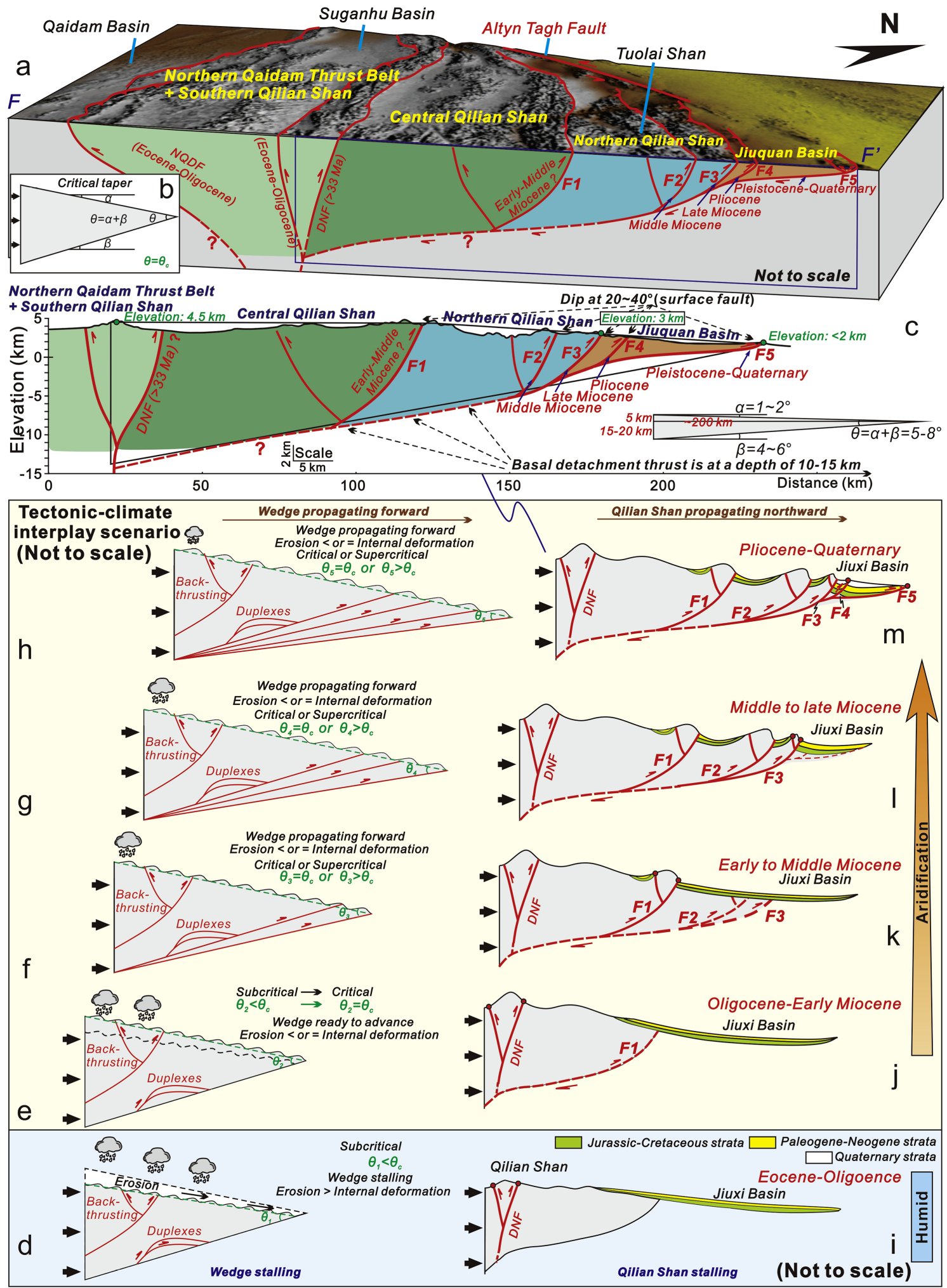

